\title{
U.S. Department of Energy Clean Cities Five-Year Strategic Plan
}

\author{
Reducing Petroleum Dependence in \\ On-Road Transportation in the United States
}

January 2011

Prepared by Cambridge Concord Associates

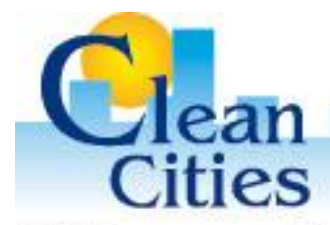

U.S. Department of Energy 


\section{Contents}

List of Abbreviations 3

Driving the Clean Cities Mission Forward

The Centrality of the Coalitions to the Success of the Clean Cities Mission 5

Executive Summary 5

Overarching Vision

Maximize the Impact of Clean Cities $\quad 7$

Strategic Direction

Significantly Expand Clean Cities' Petroleum Reduction Efforts in the 8

Portfolio of Technologies

Alternative Fuels - Electric Drive Natural Gas, Propane

Electric Drive $\quad 9$

Natural Gas $\quad 13$

$\begin{array}{ll}\text { Propane } & 17\end{array}$

Renewable Fuels - Renewable Natural Gas/Biomethane, Ethanol, Biodiesel

Renewable Natural Gas/Biomethane $\quad 20$

Ethanol/E85 23

Biodiesel/B20 26

Fuel Economy Efforts $\quad 29$

Idle Reduction - For Trucks, Buses, and Municipal Vehicles

$\begin{array}{ll}\text { Cross-Technology Strategic Priorities } & 35\end{array}$

Organizational Strategies

Optimize Coalition Effectiveness and Sustainability 38

Increase Recognition, Build Awareness, and Educate 41

Create Strong, Innovative Partnerships 44

Appendices

A. Strategic Planning Process 46

B. Interview Participants 47 


\section{List of Abbreviations}

$\begin{array}{ll}\text { AFDC } & \text { Alternative Fuels and Advanced Vehicles Data Center } \\ \text { ARRA } & \text { American Recovery and Reinvestment Act } \\ \text { BEV } & \text { battery electric vehicle } \\ \text { CAFE } & \text { Corporate Average Fuel Economy } \\ \text { CARB } & \text { California Air Resources Board } \\ \text { CMAQ } & \text { Congestion Mitigation and Air Quality Improvement Program } \\ \text { CNG } & \text { compressed natural gas } \\ \text { DOE } & \text { U.S. Department of Energy } \\ \text { EERE } & \text { Energy Efficiency and Renewable Energy } \\ \text { EPA } & \text { U.S. Environmental Protection Agency } \\ \text { EVSE } & \text { electric vehicle service equipment } \\ \text { FFV } & \text { flexible fuel vehicle } \\ \text { GGE } & \text { gasoline gallon equivalent } \\ \text { HEV } & \text { hybrid electric vehicle } \\ \text { HHEV } & \text { heavy-duty hybrid electric vehicle } \\ \text { IR } & \text { idle reduction } \\ \text { LFG } & \text { landfill gas } \\ \text { LNG } & \text { liquefied natural gas } \\ \text { NGV } & \text { natural gas vehicle } \\ \text { OEM } & \text { original equipment manufacturer } \\ \text { PHEV } & \text { plug-in hybrid electric vehicle } \\ \text { R\&D } & \text { research and development } \\ \text { RFS } & \text { Renewable Fuel Standard } \\ \text { RNG } & \text { renewable natural gas } \\ \text { SIP } & \text { State Implementation Plan } \\ \text { SVM } & \text { small-volume manufacturer } \\ & \end{array}$




\section{Driving the Clean Cities Mission Forward}

Clean Cities is a government-industry partnership sponsored by the U.S. Department of Energy's (DOE) Vehicle Technologies Program, which is part of the Office of Energy Efficiency and Renewable Energy. Working with its network of about 100 local coalitions and more than 6,500 stakeholders across the country, Clean Cities delivers on its mission to reduce petroleum consumption in on-road transportation. In its work to reduce petroleum use, Clean Cities focuses on a portfolio of technologies that includes electric drive, propane, natural gas, renewable natural gas/biomethane, ethanol/E85, biodiesel/B20 and higher-level blends, fuel economy, and idle reduction. Over the past 17 years, Clean Cities coalitions have displaced more than 2.4 billion gallons of petroleum; they are on track to displace 2.5 billion gallons of gasoline per year by 2020 .

This Clean Cities Strategic Plan lays out an aggressive five-year agenda to help DOE Clean Cities and its network of coalitions and stakeholders accelerate the deployment of alternative fuel and advanced technology vehicles, while also expanding the supporting infrastructure to reduce petroleum use. Today, Clean Cities has a far larger opportunity to make an impact than at any time in its history because of its unprecedented $\$ 300$ million allocation for community-based deployment projects from the American Recovery and Reinvestment Act (ARRA) (see box below). Moreover, the Clean Cities annual budget has risen to \$25 million for FY2010 and \$35 million has been requested for FY2011.

Designed as a living document, this strategic plan is grounded in the understanding that priorities will change annually as evolving technical, political, economic, business, and social considerations are woven into project decisions and funding allocations. The plan does not intend to lock Clean Cities into pathways that cannot change. Instead, with technology deployment at its core, the plan serves as a guide for decision-making at both the national and local levels of Clean Cities over the next five years. The plan recognizes the need for flexibility and sets out a strategic direction that will build on the progress of current technologies and new opportunities presented in emerging fuels and technologies, such as hydrogen and fuel cells, as well as new niche markets such as off-road applications that build additional throughput at existing alternative fuel stations.

\section{Geographic Distribution of Clean Cities Recovery Act Awards}

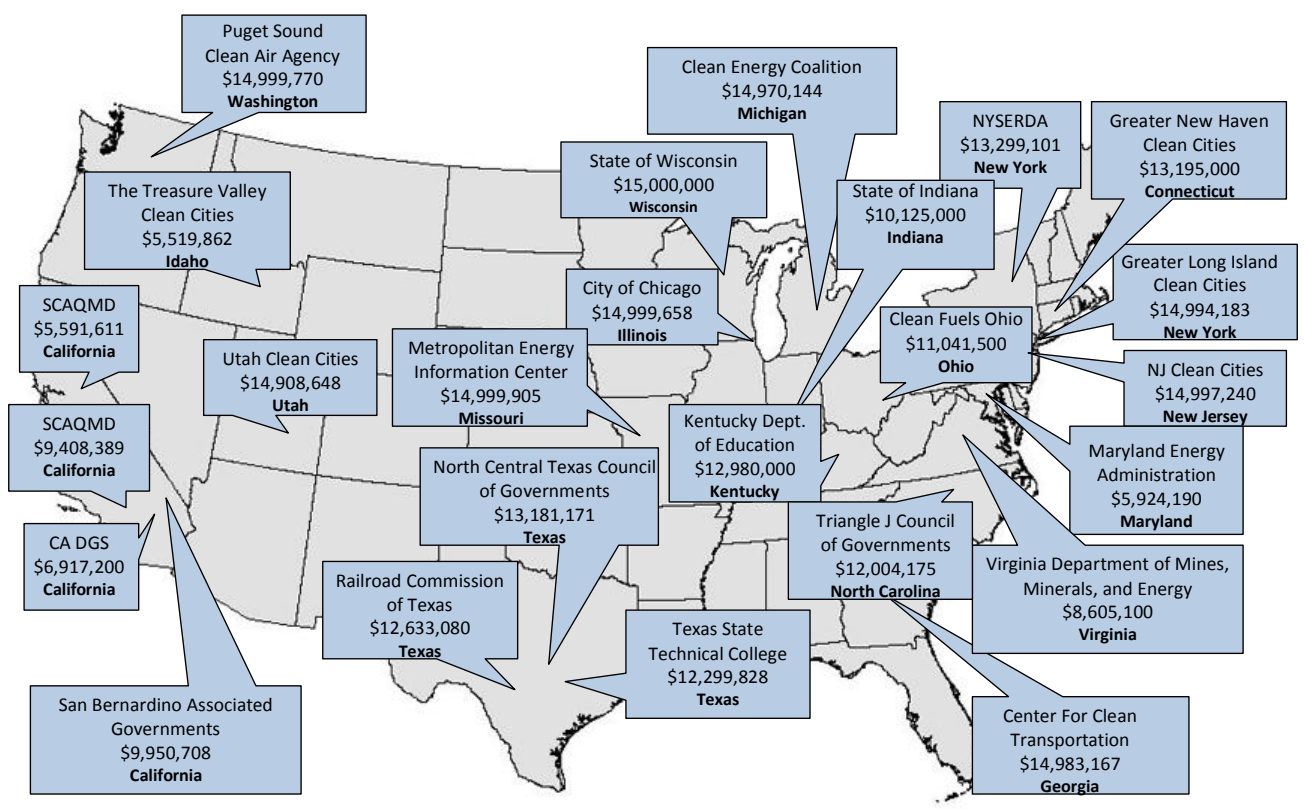

Clean Cities 2009/2010 Awards

- Biofuel retail infrastructure 6 awards: $\$ 9.9 \mathrm{MM}$

- Terminal blending and other infrastructure 7 awards: \$8.6 MM

- Incremental cost of dedicated alternative fuel vehicles 7 awards: \$22.8 MM

- Education and outreach workshops 3 awards: \$3.8 MM

- Advanced technologies and alternative fuel vehicles (ARRA) 25 awards: \$832 MM

Total 48 awards, $\$ 877 \mathrm{MM}^{\star}$

*The $\$ 877$ MM total includes cost sharing with partners on all projects listed above. 


\section{The Centrality of the Coalitions to the Success of Clean Cities Mission}

The Clean Cities coalitions work in partnership across the country to reduce the use of petroleum in the United States. The approximately 100 coalitions (see map below) include more than 6,500 public and private stakeholders from businesses, city and state governments, the automotive industry, fuel providers, and community organizations. Over the past 17 years, DOE Clean Cities has helped support coalition activities and has provided training and educational opportunities for Clean Cities coordinators. Clean Cities also provides competitive funding opportunities for projects that deploy the vehicle technologies in the Clean Cities portfolio.

This five-year Clean Cities Strategic Plan is the result of extensive research and participation on the part of Clean Cities program staff, coordinators, and stakeholders; national laboratory technology experts; industry; and partner organizations. The plan is designed to guide decision-making for Clean Cities nationally and through the work of the coalitions in achieving their local objectives. Recognizing that Clean Cities coalitions and their stakeholders increase their effectiveness over time by moving from tactical actions to more strategic decision-making and intentional initiatives, coalition coordinators are encouraged to review this plan to consider how it informs and helps prioritize their work. Industry also can use this plan to envision partnership opportunities that will develop the marketplace further. By design, the plan aims to leverage the strengths, capabilities, and resources of Clean Cities and its coalitions by providing them with support and tools to help them strengthen their effectiveness and maximize their potential to achieve their goals over the next several years.

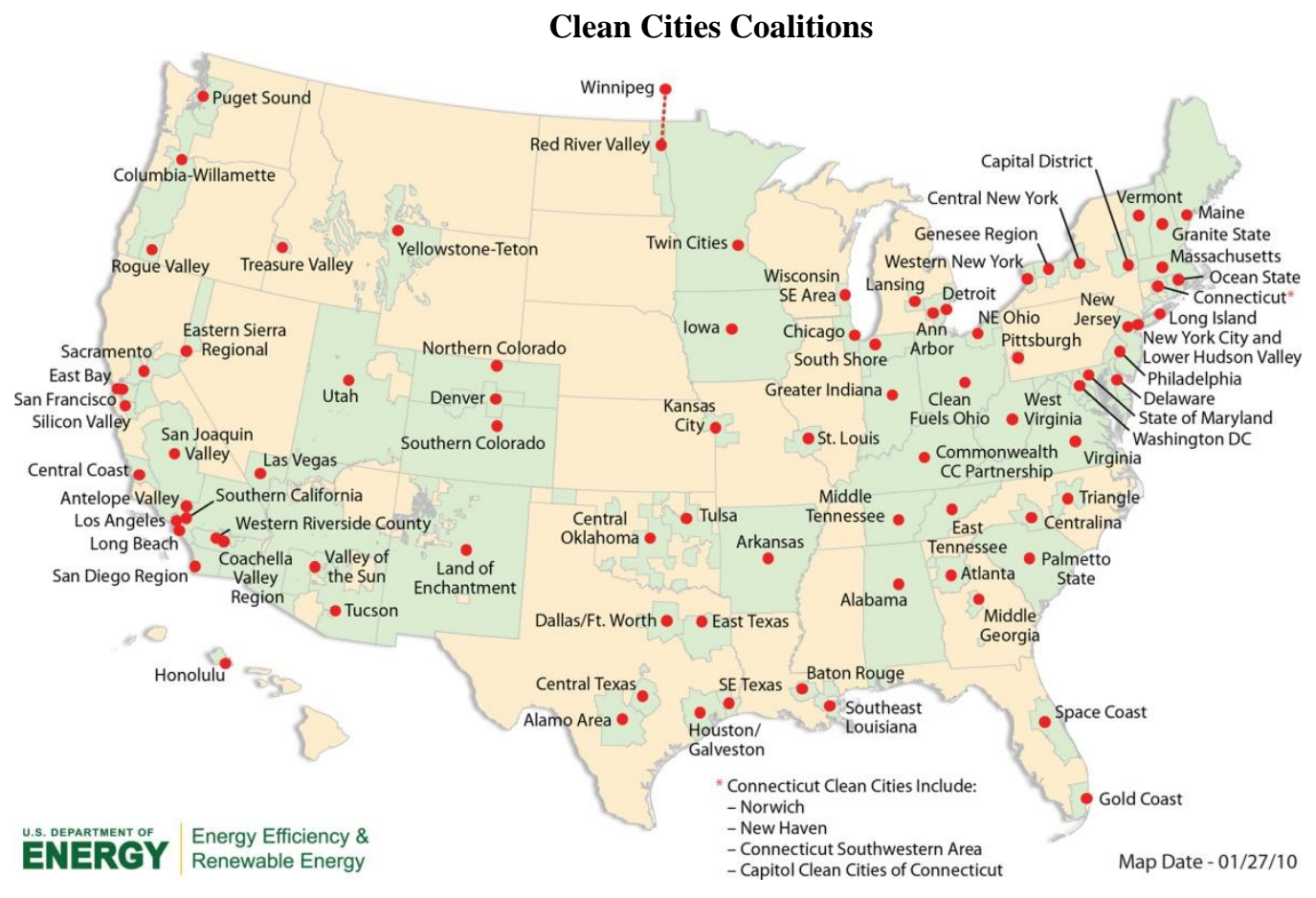

Top 15-Year Accomplishments by Clean Cities and Coalitions

Petroleum Displacement

- Displaced 2.4 billion gal of petroleum since 1993 (15 MM in 1994; $412 \mathrm{MM}$ in 2008)

- At current growth of $16 \% /$ year, will displace 2.5 billion gal/year by 2020

Fuel Economy Guide

- $39 \mathrm{MM}$ visits/year

- 125 MM GGE saved FY 2008

- Mobile site for on-the-go access

Created Clean Cities and AFDC Websites

- Premier advanced transportation resource

- More than 3,000 documents and tools

- $7 \mathrm{MM}$ hits in 2008

Major Increase in Alternative Fuel Transit Buses

- $20 \%$ alternative fueled in $\mathrm{FY}$ 2008 (vs. 6\% in FY 1997)

- Coalitions/stakeholders responsible for more than half

Helping Green National Parks

- Air quality improvements and wildlife preservation

- Visitor education/inspiration

Alternative Fuel Corridors

- $\$ 42 \mathrm{MM}$ to infrastructure, 1998-2009 (excluding ARRA funds)

- Biofuels I-65 and in OR, NY, PA, MD, VA, DC

- Other fuels (e.g., natural gas in CA, UT, NY)

Turning Garbage into Renewable Natural Gas

- Deploying biomethane technology from DOE R\&D

- Successful refuse truck tests

- Potential 500 landfills each producing $20,000 \mathrm{gal} /$ day liquefied natural gas 
Clean Cities Strategic Plan represents a fiveyear timeframe to be reviewed and updated on a yearly basis.

The mission is a statement of purpose for Clean Cities.

The primary goal lays out its essential aim.

The overarching vision puts forth an aggressive objective to achieve over the next five years.

The strategic direction indicates the primary area of focus and investment over the next five years.

The organizational strategies represent the capacity-building work to support and enable mission success.

\section{Executive Summary DOE/Clean Cities Five-Year Strategic Plan}

\author{
Reducing Petroleum Dependence in \\ On-Road Transportation in the United States
}

\section{Clean Cities Mission}

The Clean Cities mission is to advance the energy, economic, and environmental security of the United States by supporting local decisions that result in the reduction of petroleum use in the transportation sector.

\section{Primary Goal}

The primary goal of Clean Cities is to reduce U.S. petroleum use by 2.5 billion gallons per year by 2020.

\section{Overarching Vision \\ Maximize the Impact of Clean Cities}

Clean Cities is positioned to maximize its impact over the next five years by partnering with key stakeholders, engaging the public, and strengthening the effectiveness of its network of coalitions while ensuring that education and deployment are at the core of all of its initiatives.

\section{Strategic Direction \\ Significantly Expand Clean Cities Petroleum Reduction Efforts in the Portfolio of Technologies}

Over the next five years, Clean Cities will leverage its technology portfolio for greatest impact by deploying each technology in ways that build on its unique strengths, address specific regional/local needs, and promote the technology's essential role in reducing petroleum use.

Alternative Fuels: Electric Drive, Natural Gas, Propane

Renewable Fuels: Renewable Natural Gas/Biomethane, Ethanol/E85, Biodiesel/B20 and higher

Fuel Economy Efforts: Smarter Vehicle Purchasing and Driving Habits

Idle Reduction: For Trucks, Buses, and Municipal Vehicles

Other Emerging Fuels, Technologies, Niche Markets: Hydrogen, Fuel Cells, etc., as they become market ready and additional niche markets emerge

\section{Organizational Strategies}

Optimize Coalition Effectiveness and Sustainability

Optimize coalition leadership, engagement, and communication effectiveness to ensure long-term regional growth and sustainability in reducing petroleum use in on-road vehicles.

Increase Recognition, Build Awareness, and Educate

Increase the recognition and awareness for Clean Cities and its coalitions as a leading source of information about alternative fuels and advanced vehicle technologies, and educate organizations, government, and the public about how to reduce petroleum use in on-road vehicles.

\section{Create Strong, Innovative Partnerships}

Create strong, innovative partnerships to drive the growth and reach of Clean Cities at the national level and through its local coalitions for greatest impact - recognizing that partners will extend coalition opportunity and stability. 


\section{Overarching Vision \\ Maximize the Impact of Clean Cities}

Clean Cities is positioned to maximize its impact over the next five years by partnering with key stakeholders, engaging the public, and strengthening the effectiveness of its network of coalitions - while ensuring that education and deployment are at the core of all its initiatives.

Developed during the past 17 years, the DOE Clean Cities program has achieved significant results through its highly effective network of community-based coalitions and strong public-private partnerships at both the national and local levels. Building on this solid base, and considering the dramatic leap in projects funded by ARRA, Clean Cities is in a position to maximize its impact significantly over the next five years.

Barriers exist for advanced technology vehicles and alternative fuels, all of which are at different stages of development and deployment. Industry remains capacity limited, with only the beginnings of fueling infrastructure in place, too few vehicle platforms, pricing issues to be solved, budget uncertainties, and a lack of understanding at the local level by regulatory officials, fleets, and the general public of the benefits of these technologies. However, Clean Cities has a strong base in place through its local partnerships to help individuals, businesses, and government work together to transform how this country fuels automobiles and trucks in ways that significantly reduce petroleum use. Historically, the focus has been on educating fleet customers on alternative fuels and advanced technology vehicles. That focus will remain. In addition, with the promotion of fuel economy, ethanol/E85, and now, electric drive technologies, strategies to inform the general public will be emphasized, as well.

Through communication and education initiatives, Clean Cities will provide information that private and government fleets and consumers need to choose the right alternative fuel vehicles and advanced vehicle technologies for their situations. At the same time, Clean Cities will work with business, municipal, and government fleets and other partners across the country to learn from diverse vehicle technology deployment projects funded by ARRA about what works or does not.

Education and knowledge-sharing are fundamental to engage the public - including fleet managers and general consumers - in making decisions to choose the alternative fuel or advanced technology vehicle that is best for their needs. DOE Clean Cities is committed to:

- Ensuring that coordinators and coalition stakeholders have the information and tools they need to involve the public in their initiatives in proven and creative ways.

- Providing the education and training, tools, and support that fleet managers and consumers need to learn what impact they can have by making the right transportation choices.

- Studying, learning from, and sharing the results of the unprecedented number of ARRA-funded and other projects to build future successes.

The ability of Clean Cities to effectively involve the public - including fleet managers and consumers - is critical for achieving its goals over the next five years. Moreover, Clean Cities has the opportunity to create new standards and models by measuring and learning from current initiatives, particularly from the ARRA-funded projects. 


\section{Strategic Direction \\ Significantly Expand Clean Cities Petroleum Reduction Efforts in the Portfolio of Technologies}

Over the next five years, Clean Cities will leverage its technology portfolio for greatest impact by deploying each technology in ways that build on its unique strengths, address specific regional/local needs, and promote the technology's essential role in reducing petroleum use.

\section{Portfolio of Technologies}

In collaboration with its coalitions and stakeholders, Clean Cities will play a leadership role in:

\section{Alternative Fuels - Electric Drive Natural Gas, Propane}

- Electric Drive - Expedite the planning for and development of infrastructure and the targeted growth of the marketplace for electric drive vehicles.

- Natural Gas - Accelerate natural gas vehicle market deployment by addressing technical barriers and focusing on infrastructure expansion and vehicle availability.

- Propane - Accelerate propane vehicle deployment efforts by addressing technical barriers and focusing on infrastructure expansion and vehicle availability.

\section{Renewable Fuels - Renewable Natural Gas/Biomethane, Ethanol/E85, Biodiesel/B20}

- Renewable Natural Gas/Biomethane - Expand market awareness for renewable natural gas/ biomethane as a vehicle fuel, and cultivate innovative eco-oriented business partnerships.

- Ethanol/E85 - Accelerate regional collaboration among fleets and consumers to facilitate ethanol/E85 market expansion and greater availability of flex-fuel vehicles.

- Biodiesel/B20 - Accelerate biodiesel (B20 and higher) market development by addressing technical barriers and focusing on infrastructure expansion and vehicle compatibility.

\section{Fuel Economy Efforts - Smarter Vehicle Purchasing and Driving Habits}

- Fuel Economy - Educate the consumer, business, and government about their choices of vehicles and fuels so they can make smarter purchasing and driving decisions for the highest impact on fuel economy.

Idle Reduction - For Trucks, Buses, and Municipal Vehicles

- Idle Reduction - Advance widespread adoption of idle reduction technology practices for trucks, buses, and motor vehicles; validate the financial, energy, environmental, and health benefits; and promote idle reduction for commercial and public drivers. 


\section{Strategic Direction-Alternative Fuels}

\section{Electric Drive}

\section{Expedite the planning for and development of infrastructure and the targeted growth of the marketplace for electric drive vehicles.}

\section{The Case for Strategic Priorities}

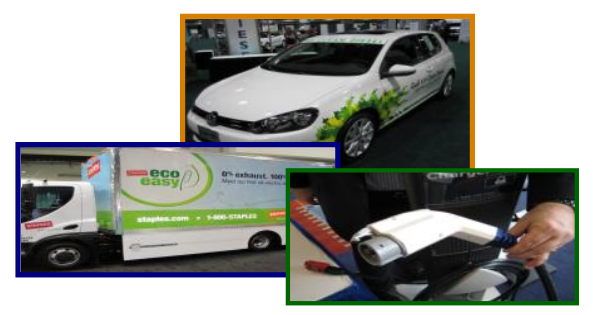

\section{Current Status -}

During the past seven to eight years, the number of hybrid electric vehicles (HEVs) in the United States has grown to more than 1 million. In 2008 alone, Clean Cities contributed 12 million gasoline gallon equivalents (GGE) of petroleum displacement from HEVs and heavy-duty hybrid electric vehicles (HHEVs). Moreover, a new generation of battery technologies with greater storage capacity has encouraged the federal government to set a goal for 1 million plug-in hybrid electric vehicles (PHEVs) on the road by 2015. (In this context, electric drive includes HEVs, PHEVs, and battery electric vehicles [BEVs], with the common theme of powertrains using electricity generated by means other than oil-derived fossil fuel.) Because it is unclear which electric drive technologies will succeed, investment funds are spread across a range of technologies and vehicle classes. The market is gaining attention as numerous original equipment manufacturers (OEMs), electric drive component manufacturers, and electric vehicle service equipment (EVSE) manufacturers announce upcoming electric drive products and market directly to early fleet and individual adopters of new technologies. Nissan and GM both announced national rollouts of their electric drive models by the end of 2011 .

\section{Future Prospects -}

Due to the emergence and promise of numerous new battery chemistries based on the use of lithium, plug-in electric drive is now quite promising. BEVs will likely appear earlier than PHEVs. Initially, light electric trucks are anticipated to serve commercial and public fleets that operate in cities at very low average speeds. At somewhat higher average speeds, very common in cities and highdensity suburbs, small and mid-size BEVs will increasingly compete with "conventional" HEVs for household use. In comparison, PHEVs are anticipated to be mid-size passenger vehicles for households predominantly in suburban locations with garages or carports - and will represent some driving on interstate highways with higher average speeds than pure BEVs.

Within metro areas, BEVs will require in-house infrastructure upgrades and a judiciously planned public charging infrastructure to succeed. PHEVs will not require, but would often benefit from, within-house infrastructure upgrades and workplace chargers. Public recharging would be the least important infrastructure for PHEVs. (HEVs, of course, will not plug in.) For electric drive to continue to expand its market share in personal vehicles, cost-effective infrastructure planning and implementation is needed.

Within the heavy-duty commercial vehicle and public fleet sectors, HHEVs have been proven in small volumes in niche applications where a high percent of operating time at idle is inherent in the vehicle's use. Transit buses, 
parcel delivery trucks, and garbage trucks are examples. As mass production brings down costs and performance is improved by technological innovation, heavy-duty vehicle suppliers will increasingly adapt advanced technology battery cells to battery packs, expanding the use of HHEVs and heavy-duty plug-ins, and helping trucks meet near-future fuel consumption standards.

\section{DOE/Clean Cities Role -}

The accelerating marketplace is driven in part by the DOE Office of Vehicle Technologies' Transportation Electrification ARRA grants that allow BEV/PHEV early adopters to demonstrate and deploy these state-of-theart vehicles and their infrastructure. The Transportation Electrification grants and the Clean Cities ARRA grants will create a framework for lessons learned from early adopters and manufacturers. ARRA also has provided \$6 billion in loan guarantees, $\$ 2$ billion for advanced battery manufacturing, and about $\$ 40$ million for training.

As it has for HEVs and HHEVs, Clean Cities will continue to play an increasingly valuable role as a leading source of unbiased information on emerging electric drive technologies (BEVs and PHEVs). Clean Cities will educate coordinators, stakeholders, and the public about best applications for use, opportunities and risks, economics and the business case (including tax credit and nonmonetary incentives), and community planning needs and considerations - specifically, helping to prepare communities for the introduction of electric vehicles (e.g., expediting permitting and installation). How to appropriately manage the high expectations that often accompany exciting new technologies will also be included. To communicate this information, Clean Cities will engage electric drive experts in meetings, webinars, and on-line training.

Clean Cities will provide coordinators and their coalition stakeholders with tools to work effectively with electric drive OEMs and dealerships in their regions and with various stakeholders (e.g., electric utilities, city and state governments, and fleets) to develop markets for electric drive - initially in cities targeted by OEMs. Clean Cities may find opportunities locally to sponsor events to showcase these new technologies, giving the public the opportunity to try out first-generation BEVs and PHEVs. Training grants funded by ARRA will educate students from high school through graduate level. Clean Cities will coordinate with recipients to ensure regionally appropriate educational materials are shared with local coalitions and educators. Training programs will also provide critical information to educators, communities' first responders, fleet personnel, and technicians. Clean Cities can be the conduit that brings together all of these activities to help electric drive cities expand.

Key Audiences for Electric Drive Technologies - fleets, individuals who are early technology adopters, OEMs, engine manufacturers and dealers, electric utilities and other electricity providers, municipal planning officials, parking garage companies, first responders, and recharging installers (electric contractors).

\section{3-5 Year Strategic Priorities}

A. Advance electric drive technology and market development by building strong coalitions of key stakeholders and partners - including Clean Cities coordinators, electric utilities, OEMs, technology developers, and governments to build electric-drive-ready communities.

- Provide coordinators and their stakeholders with tools, mapping capabilities, information, and best practices and strategies to plan effectively with electric drive OEMs, dealerships, and various local stakeholders (e.g., electric utilities, permitting offices, fire departments, and fleets) in developing communities for electric drive - initially in cities targeted by OEMs.

- At the national level, work with electric utility organizations, nonprofits, associations (e.g., National Fire Protection Association, National Electrical Contractors Association, National Automobile Dealers Association), and government programs to determine what partnerships, funding opportunities, and education initiatives will best help coordinators and coalition stakeholders in their regions.

- Promote opportunities with dealers locally to showcase "demo" vehicles for marketing and education for fleet and early adopter audiences - as PHEVs/BEVs become more available. 


\section{B. Support planning for electric drive infrastructure in regions that are OEM target markets for deploying electric drive vehicles.}

- Choose target markets on the basis of estimates of potential oil savings and greenhouse gas $(G H G)$ reduction over the anticipated life of the vehicle classes being considered for introduction.

- In regions identified as target markets, including those chosen for product introduction by electric drive OEMs, help Clean Cities coalitions work with technology providers and regulatory bodies (e.g., independent system operators, regional transmission organizations, and public utility commissions) as they plan for electric drive infrastructure placement, development, and funding.

- Work with state and local governments to help inform and expedite the development of regulations for existing infrastructure upgrades and new construction, including timely and necessary permitting processes and inspections.

\section{Provide coordinators, coalitions, and stakeholders with best-available information about electric drive vehicles, technology, economics, markets, and infrastructure.}

- Capture key data and lessons learned, and develop case studies from the major Transportation Electrification projects funded by ARRA to generate the latest information on electric drive technology. Include:

- Electric drive vehicle initial cost, operating cost effectiveness, gasoline savings, market fit, emissions data with updates provided by new inputs into the GREET model, reliability in diverse conditions, and payback periods.

- Data about infrastructure options, such as the particular infrastructure needs of utilities, city planners, and businesses and others.

- Data about battery technology options (and prospects for recycling).

- Educate coordinators, stakeholders, dealers, and the public about the electric drive technology through webinars, meetings, a website, publications, and other educational approaches.

- Invite electric drive experts to meetings and webinars, and engage them for ongoing online training.

- Organize and package the information in presentations, publications, webinars, technology bulletins, etc., for use by Clean Cities coordinators and stakeholders.

- Provide technology bulletin updates giving communities and stakeholders the latest information about infrastructure codes and standards, electric station design and certification processes, and vehicle certification.

- Update the Alternative Fuels and Advanced Vehicles Data Center, providing information on new vehicles and charging stations, best practices, frequently asked questions, local incentives, and other sources of critical information.

\section{For coordinators and stakeholders, provide ongoing access to training about electric drive and} plug-in electric vehicles, technology, and infrastructure.

- For each type of electric drive vehicle/technology (i.e., commercial trucks, service vehicles, and small vehicles for household use), develop online and in-person training and tools for coordinators and local Clean Cities stakeholders, such as dealers and electrical contractors.

- Training should cover infrastructure, codes and standards, permitting, emission impacts, and emerging electric drive vehicle technologies.

- DOE is identifying potential training sites, planning an electric drive technology guide for coordinators, and developing online training to include lessons learned. 
- Ensure that local coalitions have access to curricula and course schedules by coordinating the efforts of the training institutions funded by the Transportation Electrification grants of ARRA.

[For additional technology information, see the Clean Cities paper: Highway Vehicle Electric Drive in the United States: Current Status and Issues.] 


\section{Strategic Direction - Alternative Fuels}

\section{$\underline{\text { Natural Gas }}$}

\section{Accelerate natural gas vehicle market deployment by addressing technical barriers and focusing on infrastructure expansion and vehicle availability.}

\section{The Case for Strategic Priorities}

\section{Current Status -}

Introduced in the 1980s in the United States to extend petroleum supplies and reduce exhaust emissions, natural gas vehicles (NGVs) initially failed to gain traction in the marketplace for a range of reasons. But NGVs are now poised for growth. Key impediments have included lack of public refueling stations, high cost of infrastructure development, limited options for natural gas vehicles/engines, deregulation of the natural gas industry, and the absence of a business case for fleets. More recently, however, a new wave of NGVs has appeared and the technology has the potential for explosive growth. Worldwide, the number of NGVs grew from about 7.4 million in 2007 to 9.6 million in 2008, with an estimated 11.2 million vehicles in 2009 .

\section{Future Prospects -}

While expansion has been far more modest in the United States, recent developments suggest that rapid growth may be at hand. New technical capabilities to tap shale gas reserves have greatly expanded the supply and reduced the cost of natural gas. Other positive developments are increased vehicle availability (from new vehicle offerings and after-market conversions), technology improvements that have brought down the cost of NGVs to near-parity with diesel engines, and the availability of Clean Cities ARRA support for fleet and infrastructure development. Favorable publicity, like AT\&T's decision to invest \$565 million to deploy 15,000 alternative-fuel vehicles over time (primarily by converting its fleet to natural gas), also draws attention to the benefits of NGVs and provides additional impetus for market growth.

Natural gas utilities, once at the forefront of NGV deployment and marketing, are again investigating new business opportunities. With 156 investor-owned natural gas utilities and 8,000 natural gas suppliers operating in the United States, and investor-owned pipelines playing a more active role in the market, partnerships are ripe for development. Moreover, government pressures to reduce GHG emissions by using low-carbon fuels are driving change in the transportation sector. (According to GREET [the Greenhouse Gases, Regulated Emissions, and Energy Use in Transportation Model], using lowcarbon fuels reduces tailpipe and well-to-wheels $\mathrm{CO}_{2}$ by approximately $20 \%$ over gasoline. But methane emissions are important too, so it is closer to a $15 \%$ reduction of GHGs at this time, although California says it is an up-to$30 \%$ reduction.)

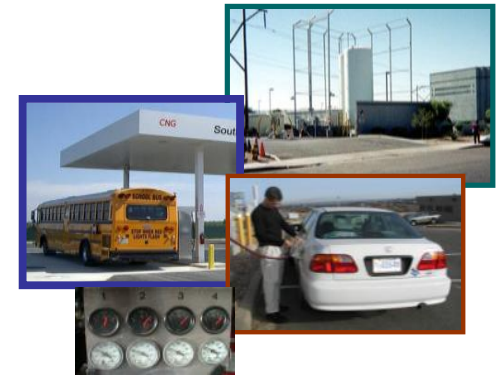

\section{Clean Cities Natural Gas}

Current Example Initiatives

- Transit and School Bus Users Group

- NGV Technology Forum

- Tiger Teams/troubleshooting

- Codes/standards development and international harmonization

- AFDC Mobile Station Locator

- "Natural Gas Infrastructure: A Suite of Tutorials"

- "Business Case for Compressed Natural Gas in Municipal Fleets"

- Conversion guide; "Heavy-Duty Buyers Guide for Fleet Managers"

- Workshops for coordinators, fleets, and first responders via the National Alternative Fuel Training Consortium, North Carolina State, and Alternative Fuel Trade Alliance

- Shale gas pathway in GREET

\section{3-5 Year Selected Priorities}

- On a regional basis, work with natural gas utilities, fleets, transportation agencies, state and local governments, and partners to expand natural gas markets.

- Develop and share new/updated information and performance data to support NG vehicle market expansion - including the business case, vehicle performance, and product and technology updates.

- Provide technical assistance and training workshops that support NG project completion, standards setting, regulatory requirements - and that need industry and government collaboration for success.

- Develop opportunities for government and industry to work on engine development for medium- and heavyduty trucks and buses on an ongoing basis. 
More than 40 different global manufacturers produce NGV systems. In the United States, small-volume manufacturers (SVMs) produce light- and medium-duty NGVs and fuel systems for dedicated or bi-fuel operation. Additionally, natural gas engines certified to 2010 EPA/CARB emission standards are being retrofitted, repowered, or manufactured to serve U.S. fleet customers. Renewed interest by the manufacturing sector in producing this type of vehicle technology generates customer confidence that servicing will be available, as will products for future fleet purchases.

\section{DOE/Clean Cities Role -}

Through a range of initiatives during the past 15 years, the NGV industry and Clean Cities have worked in tandem to create new opportunities in niche markets, such as transit buses, taxis, school buses, and refuse fleets. Example initiatives include: hosting fleet workshops, funding vehicle and infrastructure projects, developing case studies and other tools, and facilitating partnerships among fuel providers, fleets, and manufacturers. As the favorable developments mentioned above have occurred, all of these niche markets have seen growing interest in natural gas as a vehicle fuel.

Unprecedented funding levels from the ARRA have empowered Clean Cities to "make the business case" for NGVs and infrastructure by expediting the development of new fueling facilities within communities and along inter-regional corridors, using compressed natural gas $(\mathrm{CNG})$ fleet vehicles in niche markets, and expanding the use of liquefied natural gas (LNG) heavy-duty trucks. To illustrate the scale of these initiatives: Over the next four years, ARRA and other award recipients will purchase more than 3,100 CNG and LNG vehicles and construct an extensive refueling network of 131 natural gas stations. In addition to capital support, Clean Cities plans to document some of these projects as case studies to help other fleets and organizations, such as utilities and city and state governments, overcome hurdles and expand their natural gas use. Clean Cities is also funding educational efforts for safety officials, cylinder inspectors, fleet managers, and vehicle technicians on NGV technology. Efforts could be duplicated in underserved areas of the country and facilitate greater growth.

Key Constituencies for Natural Gas - municipal fleets (e.g., refuse haulers), local utilities, state fleets, private fleets (e.g., taxis), commercial urban delivery trucks, manufacturing facilities, transit buses, and farm-use vehicles.

\section{3-5 Year Strategic Priorities}

\section{A. On a regional basis, work with natural gas utilities, transportation agencies, fleets, state and local governments, and other partners to expand natural gas markets.}

- Transit, Refuse, and School Buses: Expedite work with transit agencies and school bus agencies to choose natural gas as a way to cut air pollution and boost energy security. (Because the demand for transit services has grown as the economy has declined, agency savings can increase with the use of natural gas.)

- Continue to convene the Natural Gas Transit and School Bus Users Group to discuss solutions and success strategies for existing and potential new transit and school bus fleet operators. (Expand to include a "help desk" to support agencies and to include refuse managers in discussion groups.)

- Publicly recognize transit agencies, waste management companies, and school districts that have made significant strides in NGV deployment.

- Disseminate information and research to support the business case for natural gas transit, refuse, and school buses (e.g., Business Case for Compressed Natural Gas in Municipal Fleets, www.afdc.energy.gov/afdc/pdfs/47919.pdf).

- Corporations: Present natural gas options to key national corporations (list already developed) that own and manage private fleets or can influence suppliers; share lessons learned by earlyadopter fleets. 
- Develop a corporate natural gas awards program that recognizes fleets making significant NGV purchases (potentially tying this initiative into the Clean Cities National Partners program).

- Work with successful NGV fleet managers (or identify retired successful senior fleet managers for a "Loaned Senior Executive" program) to share their lessons-learned experiences with fleet managers considering the switch to natural gas.

- State and local governments: Present new findings and case studies in front of national groups of decision makers, such as meetings/briefings tied to the Department of Transportation, National League of Cities, U.S. Conference of Mayors, National Governors' Association, National Association of State Energy Officials, and the American Public Transit Association.

- Develop a state/local government natural gas awards program that recognizes successful fleet managers at the state/local level for making significant NGV purchases.

- Natural gas utilities: Re-engage natural gas utilities in Clean Cities by making the business case for the benefits of using NGVs in their utility fleets, providing them with lessons learned, helping them promote NGVs to other fleets and consumers in their local communities, and engaging them in Clean Cities local activities.

- Natural gas suppliers: Identify natural gas suppliers by region (from the 8,000 suppliers in the United States), and develop opportunities for coalitions to work with local natural gas suppliers.

- Natural gas associations: Engage with national natural gas associations (e.g., American Gas Association, America's Natural Gas Alliance, etc.) to share research and data that informs the business case for NGV fleets and other uses.

\section{B. Develop and share new/updated information and performance data to support natural gas vehicle market expansion - including information/data about the business case, vehicle performance, and product and technology updates.}

- Develop new information on taxi, shuttle bus, trash and recycling trucks, delivery vehicles, and short/long-haul trucks fleet performance on natural gas, such as emissions for criteria pollutants and GHG, economic comparisons, performance, and information about infrastructure development.

- Place a renewed emphasis on intra-city truck fleets (delivery and repair) by understanding typical fleet turnover rates, fueling patterns, driving range requirements, types of vehicles operated, and annual fuel consumption.

- Present information on the findings from the ARRA natural gas vehicle and infrastructure projects to relevant audiences by using case studies and making presentations on these findings at niche association meetings, such as trucking expos, taxi and limo associations, and school bus fleet or administrators' conferences.

- Package information/data (including updated performance and emissions data) for use by Clean Cities coalitions.

- Develop and package business case information for coordinators and stakeholders to provide to transit agencies, local transit boards, and other fleets.

- Include information about the total-investment payback period for a fleet, including the initial vehicle cost, and operating cost (fuel, maintenance, product longevity, insurance rates, and resale value) as a means of supporting the growth of NGVs in general and transit buses.

- Conduct economic analysis of a strong NGV industry to provide relevant findings to appropriate state and local policy makers.

- $\quad$ Track the deployment of vehicles in niche markets that run on CNG/LNG as Clean Cities deploys ARRA funding to expedite natural gas market expansion and extensive refueling network along 
inter-regional corridors. Include deployment of CNG fleet vehicles in niche markets, LNG heavyduty trucks, and switchyard locomotives that run on LNG.

- Continue to develop web resources to keep abreast of the rapidly changing NGV product range, including engines and platforms for heavy-duty vehicles, OEM natural gas light- and mediumduty vehicles and certified conversion equipment; and critical information and procedures on the installation of natural gas stations.

- Shale Gas GHG benefits: Add shale gas to the GREET analysis for determining the carbon footprint of this fuel.

- Evaluate the costs and benefits of off-road natural gas options. While Clean Cities is focused on on-road vehicles, off-road vehicles can potentially help build and contribute to an economical natural gas infrastructure.

\section{Provide technical assistance and training workshops that support natural gas project completion, standards setting, and regulatory requirements.}

- Clean Cities NGV project support: Develop new tiger teams that will troubleshoot issues pertaining to NGVs and infrastructure projects.

- Codes and standards: Continue to support industry and its work with LNG and CNG codes and standards, such as language to be used on CNG cylinders, natural gas dispersion modeling related to potential ignitable mixtures, inspection date marking, and guidance for maintenance facilities.

- Technician training: Because technician training seems to be lacking in some areas of the country, analyze where best to provide training, what types of courses are needed (e.g., cylinder safety and inspection), and ways to spur involvement of community colleges and other automotive technician training schools. Analysis should include current Clean Cities NGV maintenance training programs funded by Clean Cities in 2009 and other programs offered by groups such as the National Alternative Fuels Training Consortium to examine regional needs and areas of potential NGV growth.

\section{Develop opportunities for government and industry to work on engine development for medium- and heavy-duty trucks and buses on an ongoing basis.}

- Bring together local, state, and federal government and industry to expedite new engine development to provide additional models for fleet customers.

[For additional technology information, see the Clean Cities paper: Natural Gas Vehicles: Status, Barriers, and Opportunities.] 


\section{Strategic Direction - Alternative Fuels}

\section{Propane}

\section{Accelerate propane vehicle deployment efforts by addressing technical barriers and focusing on infrastructure expansion and vehicle availability.}

\section{The Case for Strategic Priorities}

\section{Current Status -}

Propane is the most widely used alternative fuel in vehicles, representing more than 13 million vehicles globally, including 7 million vehicles in Europe, with only about 158,000 in the United States. In this country, based on 2005 data, North Carolina, California, and Texas are the largest users of propane as a transportation fuel (Texas Comptroller of Public Accounts). Propane is a nontoxic, noncarcinogenic, and noncorrosive fuel that poses no risk to groundwater, surface water, or soil. In addition, propane provides GHG reduction benefits because its emissions are 15-20\% lower than gasoline. Moreover, recent demonstrations of liquid propane injection technology have shown it can improve fuel efficiency, which will further reduce propane's GHG emissions.

In 2008, Clean Cities coalitions displaced 25 million GGEs through the use of propane, which was down from 30 million in 2007. Contributing factors to the decrease in propane's use as a transportation fuel may include retirement of older vehicles, a lack of new models, insufficient propane availability, and the vulnerability of propane to price spikes (especially in the peak heating season). Important to the future is the ability for propane to remain cost-competitive as a transportation fuel. Propane fleets are most cost effective when they secure propane on long-term, fixed-price contracts and are based near major natural gas liquid pipelines and/or near large aboveground storage tanks (available at 25,000 retail propane dealers nationwide). Current U.S. and Canadian propane production levels (58 million tons) are estimated to remain constant through 2012. One major source of propane, domestic conventional natural gas production, has been declining; however, new unconventional natural gas supplies are offsetting that production loss.

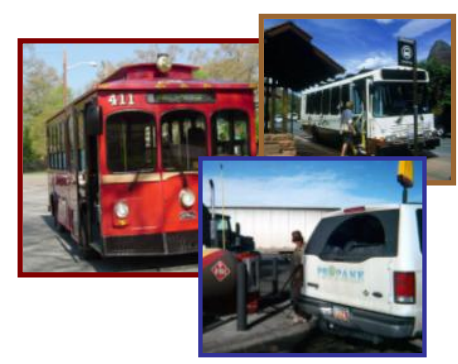

\section{Clean Cities Propane}

Current Example Initiatives

- Monthly propane vehicle webinars and vehicle road shows hosted by industry

- Clean Cities/ARRA funding for $\sim 3,000$ LPG vehicles and 249 stations to grow the autogas market

- Companion training programs for first responders, fleets, and coordinators

- Alternative Fuels Data Center promotion of propane-fueled vehicles as an alternative to gasoline (information about refueling locations, vehicles, infrastructure developments, propane fuel prices)

\section{3-5 Year Selected Priorities}

- Educate, maximize learning, and promote the business case for propane products to support market development.

- Work with partners to support and expand infrastructure development for propane on a regional basis.

- Partner with industry to make more technical education and training available to its constituencies.

\section{Future Prospects -}

Current niche markets that the industry and Clean Cities may focus on include school and activity buses, taxis, police vehicles, paratransit buses, national park buses, and shuttle and tour buses. Diesel currently fuels the majority of U.S. school buses. However, because air pollutants in diesel exhaust pose a hazard to public health, school districts are considering moving to alternative fuels such as propane and compressed natural gas. Propane now fuels about 2,000 of the approximately 505,000 school buses transporting U.S. school children each school day. One manufacturer, Blue Bird Corporation, projects that 14,200 propane-fueled school buses will be on the road by 2013 .

The lack of new propane-fueled vehicles is improving through several market-development partnerships initiated by industry. Moreover, in September 2009, in addition to other propane projects, DOE awarded \$12.2 million in ARRA grants to Texas State Technical College to establish more than 180 propane fueling sites at retail stations with its partners. These partners, including ConocoPhillips, are supported by Clean Cities coalitions and industry. Across two phases, stations are being installed in 19 major cities over the next few years. 


\section{DOE/Clean Cities Role -}

Looking ahead, the number of vehicles and stations to be deployed as the result of ARRA funding has the ability to catapult the market. Similarly, Clean Cities has the ability to influence propane use in many areas, including numerous niche markets, such as school buses, taxi and police fleets, paratransit, and farm vehicles. Clean Cities can provide stakeholders with information on topics such as propane supply, emissions and durability testing, fuel economy and performance, safety concerns, and the business case, including payback period for total investment.

Key Constituencies for Propane - state propane associations; taxi, police, school bus, and paratransit bus fleets; manufacturing; and fuel marketers.

\section{3-5 Year Strategic Priorities}

\section{A. Educate, maximize learning, and promote the business case for propane products to support market development.}

- Business case: Develop and promote an updated business case for propane as a smart, alternative fuel that emphasizes the fuel efficiency and economic benefits of new clean propane technologies/products.

- Develop a paper and media/communication outreach on the business case for propane use in vehicles and work with industry to strengthen recognition for propane.

- Renew the emphasis on fuel distributors and key niche markets - such as school buses, taxicabs, police vehicles, and paratransit buses - by developing materials about supply of propane; results from new testing of emissions, fuel economy, and performance; safety; and payback period for the total investment by a fleet.

- As off-road vehicle opportunities emerge and supplement existing infrastructure throughput, develop case studies evaluating the costs and benefits of off-road propane vehicles and how they can contribute to economical propane infrastructure.

- Propane grant projects: Maximize learning from the Clean Cities propane award projects already under way by helping those projects succeed, analyzing the market impact of the approximately 3,000 vehicles on the road, developing case studies, and publicizing what was learned. With this information, Clean Cities should then reach out to small-scale fuel distributors and new fleets that may not know about the benefits of propane vehicles.

\section{B. Work with partners to support and expand infrastructure development for propane on a regional basis.}

- Stations: Building on a Clean Cities national partnership program, and the recent ARRA award that will support the establishment of propane stations at ConocoPhillips-branded retail stations in 19 major cities, engage major oil companies to help promote and expand the propane market on a regional basis to include more stations. All participants will benefit from strong collaboration among retail stations, OEMs, and fleets.

- Fleets: Identify and work with fleets in the 19 cities to evolve as "anchor fleets" for the new propane stations.

- Communication: Develop/implement local and statewide communication/media initiatives to draw attention to this national partnership program - particularly in drawing attention to the participating companies and fleets.

- States and state propane associations: Identify and partner with selected state associations that are good candidates to partner with Clean Cities to promote propane as a vehicular fuel, and engage those groups in developing pilot programs - particularly focusing on states with propane experience/infrastructure already in place for nontransportation uses. Engage propane fuel marketers to support the development of propane as a vehicle fuel. 
- Industry: Partner with industry to ensure that current reliable emissions data for propane vehicles are available. Work with successful propane vehicle fleet managers (or identify successful retired senior fleet managers for a "Loaned Senior Executive" program) to share their lessons-learned experiences with fleet managers who are considering the switch to propane.

- OEMs: Work with OEMs and industry to develop more propane vehicles for the market, particularly for fleets. Help to achieve this by working with OEMs and state and local organizations to get test demonstration vehicles to fleets and buyers - particularly for school districts.

\section{Partner with industry to make more technical education and training available to its constituencies.}

- Build on 2009 Clean Cities training grants by partnering with industry to assess need and encourage further technical education/training (e.g., quality control, safety, technical assistance) to its constituencies that have not been served by Clean Cities training programs. Communicate through coalition coordinators about the availability/value of this training. (Feature training modules for coordinators through Clean Cities University.)

[For additional technology information, see Clean Cities paper: Propane Vehicles: Status, Challenges, and Opportunities.] 


\section{Strategic Direction - Renewable Fuels}

\section{Renewable Natural Gas/Biomethane}

\section{Expand market awareness for renewable natural gas/biomethane as a vehicle fuel, and cultivate innovative eco-oriented business partnerships.}

\section{The Case for Strategic Priorities}

\section{Current Status -}

Renewable natural gas/biomethane is supplied most economically from large sources of organic materials, including landfills, farms, food and agricultural waste, and wastewater treatment plants. In the United States, approximately 525 landfills, 125 dairies, 115 wastewater treatment systems, and 10 other livestock operations currently recover energy from biogas. Because of economic and regulatory incentives, most projects convert the biogas into electricity. A relatively small number of projects produce high-Btu renewable natural gas (RNG), mostly for injection into pipeline systems. These include 23 operating and four under-construction landfill gas (LFG) projects and four operating and nine planned/under-construction dairy projects. Only four projects (three from LFG and one from dairy digester gas) currently produce vehicle fuel, either pressurized or in liquid form, to fuel buses and refuse trucks or for sale into the bulk LNG market.

The benefits of RNG/biomethane as a vehicle fuel are similar to those of natural gas, including increasing energy security, paving the way for fuel cell vehicles, and improving the environment through reduced vehicle emissions. In addition, as a renewable resource, $\mathrm{RNG} /$ biomethane can displace nonrenewable resources, such as fossil-fuel-derived natural gas, gasoline, or diesel. When used instead of these fuels to power vehicles, RNG/biomethane reduces criteria pollutant emissions and may yield GHG emission reductions of as much as $75-90 \%$ over petroleum. The potential for significant carbon benefits are a clear biomethane differentiator to be evaluated and publicized. Spurred by California's Low Carbon Fuel Standard and a possible national standard, interest is growing in vehicle fuels with lower carbon footprints. (Petroleum fuels emit the equivalent of about 100,000 $\mathrm{g}$ of $\mathrm{CO}_{2}$, while North American natural gas emits $75,000 \mathrm{~g}$ and $\mathrm{RNG} / \mathrm{biomethane} \mathrm{emits} 25,000 \mathrm{~g}$ or less, depending on whether it is produced with or without grid electricity.)

\section{Future Prospects -}

Potential barriers to greater RNG/biomethane deployment include insufficient demand, lack of infrastructure and its effect on the cost of delivering the fuel, technological challenges associated with purification/liquefaction, and project installation restrictions. State and local environmental restrictions can be an especially difficult barrier, encouraging the use of landfill and digester gas for electricity over high-Btu RNG/biomethane, and increasing the time and cost of local permitting.

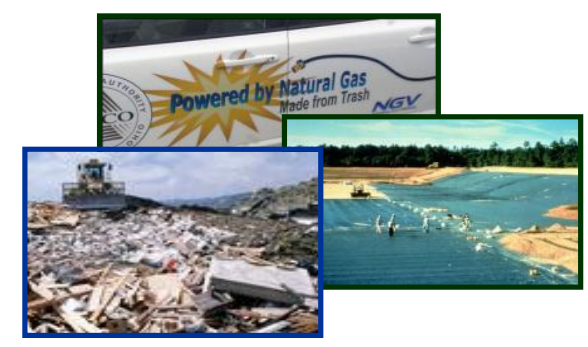

\section{Clean Cities \\ Renewable Natural Gas/ Biomethane}

Current Example Initiatives

- ARRA awards to DeKalb County/Metro Atlanta's Alternative Fuel and Advanced Technology Vehicle Project and Puget Sound Clean Cities Petroleum Reduction Project

- Recognition of Altamont landfill's LNG project with East Bay (Calif.) Clean Cities Clean Air Champion Award

- Addition of LFG-based fuels to the GREET model to facilitate benefits analysis

- Development of digester-gas-based pathways in GREET

\section{3-5 Year Strategic Priorities}

- Identify opportunities and partners, verify claims, and educate coordinators about RNG/biomethane business cases.

- Assist developers in project analysis, infrastructure deployment (including fuel stations), and fleet conversions.

- Publicize the GHG benefits of renewable natural gas in all RNG/biomethane communication initiatives

- Facilitate technology initiatives to extend and confirm benefits and reduce barriers inhibiting $\mathrm{RNG}$ /biomethane market development. 
DOE/Clean Cities Role -

Looking ahead, Clean Cities has an opportunity to introduce resource owners (e.g., utility districts, municipalities, food processors, counties, farms) to the potential of new revenue streams derived from various forms of renewable energy and low-carbon energy credits and from tipping fees at landfills or other waste processing facilities. Clean Cities can help its coalitions to engage in discussing revenue streams and project development incentives with owners and major users of landfill sites in their regions - and to convene essential private and public sector parties (including refuse haulers, landfill and compost facility operators, dairies, municipalities, utility districts, and counties) in these discussions. In addition, Clean Cities can provide technical information and assistance to project developers. Clean Cities is also in a position to gather and disseminate current federal and state data as well as review existing and proposed incentives to determine the eligibility of potential projects for such assistance.

Key Constituencies for Renewable Natural Gas/Biomethane - local utilities and fleets, including taxis, urban delivery trucks, milk trucks, waste management companies, and transit buses (to a lesser degree), as well as landfill and compost facility owners, municipalities, and utility districts.

\section{3-5 Year Strategic Priorities}

\section{A. Identify opportunities and partners, verify claims, and educate coordinators about RNG/biomethane business cases.}

- Pilot projects: Identify three or four potential pilot projects and bring together RNG/biomethane owners and stakeholders (e.g., trash haulers, natural gas suppliers, transit operators, and dairy associations) to inform them of potential revenue and incentives and to interest them in project development.

- Business case: Verify RNG/biomethane business opportunities and potential local and regional impacts and educate coordinators so they can "make the business case" with local stakeholders.

B. Assist developers in project planning and analysis, infrastructure deployment, and fleet conversions.

- Biogas-to-RNG projects: Review existing federal and state incentives that promote renewable energy production from biogas to determine their applicability to biogas-to-RNG projects and provide results to local authorities, landfill/digester owners/operators, and fleet operators.

- Fleet conversion: Work with business or municipal fleets to identify opportunities to convert portions of fleets to RNG - and document lessons learned from that process to share with other fleets.

- Infrastructure deployment: Support the development of infrastructure (including fueling stations) to move RNG/biomethane to customers (e.g., transit agencies, natural gas utilities, refuse fleets, other fleets).

- Farm use: Develop opportunities to work with EPA's AgStar program, which encourages the use of biomethane on farms.

\section{Publicize the GHG benefits of renewable natural gas in all RNG/biomethane communication initiatives.}

- Develop communication/publicity materials that coordinators can use to draw attention to the GHG benefits of RNG and to federal and state incentives for renewable energy production (see Priority B).

- Develop/release technical information and data on RNG, such as infrastructure needs, market opportunities, and barriers and incentives. (Establish Clean Cities as an authority on facts, standards, and regulations pertaining to RNG and mature natural gas technologies.)

- Facilitate access to RNG/biomethane stations (e.g., develop a way to differentiate these stations in the Advanced Vehicles Data Center [AFDC] station locator). 
D. Facilitate technology initiatives to extend and confirm benefits and reduce barriers inhibiting biomethane/RNG market development.

- Verify the benefits of biomethane/RNG on the project level (for the pilot projects in the ARRA Clean Cities awards), and in comparison with anticipated system benefits.

- Support the development of a standardized specification for RNG injected into the pipeline system. (This will reduce the time and cost of project development. RNG/biomethane project developers currently negotiate gas specification and verification requirements with each pipeline company.)

[For additional technology information, see Clean Cities paper: Renewable Natural Gas: Current Status, Challenges, and Issues.] 


\section{Strategic Direction - Renewable Fuels}

\section{Ethanol/E85}

\section{Accelerate regional collaboration among fleets and consumers to facilitate ethanol/E85 market expansion and greater availability of flex-fuel vehicles.}

\section{The Case for Strategic Priorities}

\section{Current Status -}

The U.S. production of ethanol reached 10.6 billion gallons in 2009. GREET analyses show that, compared with gasoline, E85 ethanol (15\% gasoline, $85 \%$ ethanol) delivers nearly a 70\% reduction in petroleum energy consumption throughout its life cycle. In an engine designed to take full advantage of E85, it can provide reductions in many criteria pollutants $\left(\mathrm{CO}\right.$ by $40 \%, \mathrm{NO}_{\mathrm{x}}$ by $10 \%$, VOCs by $15 \%, \mathrm{SO}_{\mathrm{x}}$ by $80 \%$, and $\mathrm{PM}$ by $20 \%$ ) - though tailpipe emissions may vary with different engine designs. E85 can only be used in flexible fuel vehicles (FFVs). The amount of gasoline in E85 is adjusted slightly by season to provide acceptable vehicle cold-starting.

\section{Future Prospects -}

Stimulated by an incentive within the Corporate Average Fuel Economy (CAFE) standard, over 7.3 million light-duty FFVs (54 light-duty models) are on the road today, representing roughly $3 \%$ of all U.S. vehicles. Furthermore, for 2012 U.S. automakers have made a commitment to manufacture $50 \%$ of their offerings as FFVs. In recent years, the U.S. market has seen the growth of E85 fueling stations (2,001 stations), primarily in the Midwest. However, in today's environment, E85 market expansion is inhibited by the limited availability of non-Midwest E85 refueling station terminals and low concentrations of flexible-fuel vehicles in areas with concentrations of E85 stations. (Also in discussion is the potential impact of a breakthrough in cellulosic technology.) In order for E85 to penetrate the marketplace successfully, stations will need a reliable source of E85 at a competitive price because it takes more E85 than gasoline to go the same distance. The equivalent of 1 gallon of gasoline is 1.4 gallons of E85. Though E85 has about $27 \%$ less energy per gallon than gasoline, E85 is typically priced lower than gasoline, so that cost per mile is comparable.

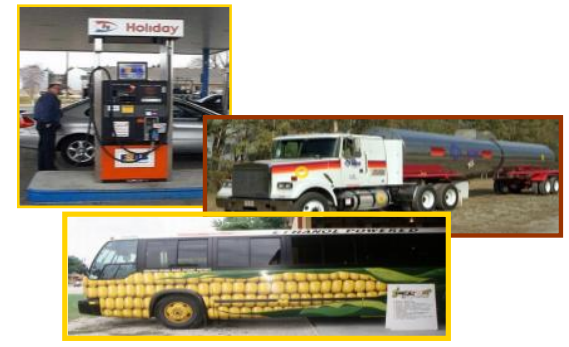

\section{Clean Cities Ethanol/E85}

Current Example Initiatives

- Grants for 180 new E85 stations in FY09/10

- EPACT workshops with mandated and voluntary fleets

- Informing consumers about flex-fue vehicle availability, fuel economics, E85 fueling stations, UL certification process, and allowable blend levels for FFVs and non-FFVs

- Dissemination of Handling and Use Guide and online tools to educate fleets/station operators

- Workshops for coordinators, fleets, first responders, etc., via National Alternative Fuel Training Consortium, North Carolina State, and the Alternative Fuel Trade Alliance

\section{3-5 Year Strategic Priorities}

- Educate fleets, consumers, and other stakeholders in E85 regions by providing best-available information to help them make the right choices about how to use E85 and to influence others to use E85.

- Develop initiatives to increase E85 volume and throughput at existing E85 stations - particularly by engaging anchor fleets for specific stations.

- Support infrastructure development for E85 selectively in regions and corridors with the greatest potential for expansion.

\section{DOE/Clean Cities Role -}

Clean Cities provides information to inform consumers (potential buyers) about the availability of FFVs, locations that sell E85 fuel, facts about E85 fuel economics, and levels of ethanol fuel blends that are allowable in FFVs. Additionally, Clean Cities' fact-based E85 information addresses petroleum independence, GHG emissions, and sustainability issues. Looking ahead, Clean Cities is working to facilitate collaboration among fleets, encourage the development of the FFV market, and affect consumer acceptance of E85 by providing information to "tell the E85 story" and eliminate confusion. Particularly important at this juncture is the need for Clean Cities and its partners to help keep existing E85 stations profitable. Toward that end, Clean Cities has the unique capability to facilitate E85 regional infrastructure development by fully engaging fleets (e.g., business, utility, government) to serve as anchors at E85 stations in their regions. Clean Cities is partnering with the 
Regulated Fleet programs to conduct a number of EPAct (Energy Policy Act) Fleet Workshops to bring together all of these key parties to the table to identify opportunities for collaboration.

Key Constituencies for Ethanol/E85 - general public who own flexible-fuel vehicles (as well as potential buyers); private fleets with light-duty truck and automobile FFVs; federal, state, and local fleets; and early adopters of new technologies.

\section{3-5 Year Strategic Priorities}

A. Educate fleets, consumers, and other stakeholders in E85 regions by providing best-available information to help them make the right choices about how to use E85 and how to influence others to use E85.

- Station Operators/Owners: Educate service station operators to make the business case for E85. Provide them with the best-available information, tools, and updated economic analyses to reflect the benefits of using high-level blends. Disseminate updated Handbook for Handling, Storing, and Dispensing E85 guide.

- Consumers: Through dealerships and public information programs, educate consumers about FFVs, the benefits of home-grown fuel, and sustainability.

- Develop outreach initiatives to connect consumers to the AFDC tools that show where to purchase E85 fuel in their regions (i.e., AFDC refueling locator, smart phone applications, mapping, Clean Cities Vehicle Buyer's Guide, and future GPS capabilities), and how to understand sustainability issues.

- Promote and provide links for consumers to learn what FFVs are available (e.g., www.fueleconomy.gov; www.afdc.energy.gov/afdc/vehicles).

- Fleets: Provide information about FFV model availability, E85 station locations, and updated business case information. (Include access to information provided in the AFDC and the fueleconomy.gov websites.)

- Direct fleet visitors to DOE Clean Cities website to fleet-specific information about E85 and other Clean Cities vehicle technologies/fuels. (See "Increase Recognition, Build Awareness, and Educate," on page 40.)

- Work with successful E85 vehicle fleet managers (or identify successful retired senior fleet managers for a "Loaned Senior Executive" program) to share their lessons-learned experiences with fleet managers who are considering the switch to E85.

- Rental Car Agencies: Work within E85 regions to educate car and light-duty truck rental agencies about the benefits of FFVs and locations of E85 stations in every state. Develop flexfuel/E85 education kits (including locations of E85 stations) for distribution to rental car/truck agencies and their customers.

- Consumer marketers: Promote Underwriters Laboratory's (UL's) final decision on certification of E85 stations to groups such as the American Automobile Association, National Association of Convenience Stores, hypermarkets, and the Independent Petroleum Marketers Association, and discuss next steps to generate additional support.

B. Develop initiatives to increase E85 volume and throughput at existing E85 stations particularly by engaging anchor fleets for specific stations.

- Anchor fleets: Build on the Clean Cities partnership initiative with the Federal Energy Management Program and DOE's State and Alternative Fuel Provider regulatory program by supporting coalition coordinators to engage regulated and commercial fleets as anchor fleets to increase E85 volume throughput at specific stations. (Focus on government fleets, utility fleets, and business fleets with FFVs.) 
- Recognize successful public and private fleet operators who have used significant volumes of E85.

\section{Support infrastructure development for E85 selectively in regions and corridors with the greatest potential for expansion.}

- Midwest: The Midwest region has very high and immediate potential for E85 growth due to the proximity of the fuel source. Evaluate new growth corridors and convene key stakeholders with the potential to expand the market.

- Other strategic locations: Working together with OEMs and the E85 industry, examine potential opportunities and approaches to support an appropriate number of new stations in strategic locations based on vehicle deployment.

- State governments: Provide Clean Cities coalitions with appropriate proven state models to approach other state governments (where relevant) to help support funding of E85 infrastructure.

- Existing station owners: Expand funding/grants to experienced station owners as an additional incentive to develop a greater refueling network in the region (or beyond) - thus increasing infrastructure availability by using experts with a good track record to develop new stations with sufficient volume.

[For additional technology information, see Clean Cities paper: Status and Issues for Ethanol (E85) in the United States.] 


\section{Strategic Direction - Renewable Fuels}

\section{Biodiesel/B20}

\section{Accelerate biodiesel (B20 and higher) market development efforts by addressing technical barriers and focusing on infrastructure expansion and vehicle compatibility.}

\section{The Case for Strategic Priorities}

\section{Current Status -}

As a highly sustainable fuel, biodiesel displaces petroleum at almost a 1:1 ratio. Life-cycle analyses show that biodiesel contains 2.5 to 3.5 units of energy for every unit of fossil energy used in its production. Moreover, the average soybased biodiesel reduces GHG by 57\%, thereby meeting the Renewable Fuel Standard (RFS) II rule - though the analysis shows a range from $22 \%$ to $87 \%$ depending on the assumptions used to predict change in indirect land-use.

The market opportunity for biodiesel fuel has gained traction with the final promulgation of the RFS II rule, with many companies supporting B20 in their production vehicles, and with the anticipated future growth of the light-duty diesel vehicle market in the U.S. In 2010-2011, as many as 30 diesel models were available in the U.S. for consumers needing sedans, vans, and pickup trucks.

\section{Future Prospects -}

Diesel sales will approximately triple in the next 10 years, accounting for more than $10 \%$ of U.S. vehicle sales by 2015 - up from $3.6 \%$ in 2005 . Looking ahead, while the RFS requires 1 billion gallons a year of bio-based diesel by 2012 , it will require additional sources of feedstocks of 21 billion gallons of advanced biofuel by 2022. That may represent a challenge for the biodiesel industry, depending on what technologies and feedstocks are used. Ultimately, additional feedstock supplies that can be sourced regionally (such as the camelina crop for producing biodiesel in Montana and the use of algae for long-term opportunities) will be required for large biodiesel markets. Consumers and policymakers will ask questions about feedstock sustainability, which will need to be addressed. Expansion of the terminal blending infrastructure will also be necessary, since the storage/blending infrastructure is available at only 70 of today's 1,500 product distribution terminals.

Unfortunately, many people continue to distrust biodiesel, or misunderstand how to use biofuels or what specific biodiesel requirements apply to their own vehicles. Moreover, they do not necessarily understand the significant benefits of biodiesel, such as reductions in GHG emissions. To expedite biodiesel market expansion, key issues must be resolved, including addressing misperceptions about biodiesel quality and sustainability, building knowledge about emissions blending protocols, developing storage and blending capabilities at terminals, educating stakeholders on the wintertime use of biodiesel, ensuring compatibility of biodiesel on post-2007 engines, and gathering data about long-term durability and compatibility.

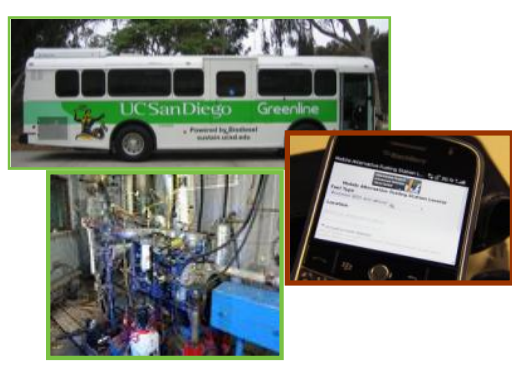

\section{Clean Cities Biodiesel}

Current Example Initiatives

- Dissemination of research reports, fact sheets, Handling and Use Guide, and online tools to educate fleets/consumers

- Workshops for coordinators, fleets, and first responders via the National Alternative Fuels Training Consortium, Alternative Fuel Trade Alliance, and North Carolina State University

- Analysis of data from trucking operators' biodiesel experience to educate others

- Leveraging industry's work with UL to test B20 blends and communicate the status

- Update of B20 station locator

- Supported $~ 40$ B20 stations with Clean Cities funding in FY09/10

- Supported seven biodiesel blending terminals with 2009 Clean Cities funding

3-5 Year Strategic Priorities

- Facilitate development of new regional and niche markets for biodiesel/B20 by working with key players to address technical issues and potential market barriers.

- Provide coordinators with business/technical information, messaging, materials/tools, and workshops to educate fleets/ stakeholders about biodiesel.

- Accelerate the gathering of needed biodiesel technical data to use through Clean Cities channels to build understanding and acceptance for biodiesel. 


\section{DOE/Clean Cities Role -}

Clean Cities is fully engaged in working with the biodiesel industry, national laboratories, and OEMs to address technical barriers and misperceptions about biodiesel to expand B20 and higher use and market growth. Through its coalitions, Clean Cities disseminates best practices and information based on solid science to educate fleets and consumers, provides training workshops, and supports testing and data gathering. In the near term, Clean Cities will work to strengthen the business case for biodiesel/B20 and higher blends, and will disseminate that information through the most appropriate communication channels - particularly for helping coalitions drive regional market expansion for biodiesel. Clean Cities will continue publicizing the benefits and test results of biodiesel use in fleets and in the laboratory, as well as updates about B20 station hours of availability and locations.

Though Clean Cities' primary biodiesel focus is B20 and higher, it will continue to investigate new or existing niche regional markets, including off-road, that hold promise for biodiesel broadly - and where Clean Cities will be called upon to provide education for the public (through the AFDC and local workshops).

Key Audiences for Biodiesel Technologies - school and transit bus agencies, fleets, mining industry, landscape industry, biodiesel fuel producers, diesel engine manufacturers, blending and refueling terminal operators, and petroleum distributors.

\section{3-5 Year Strategic Priorities}

A. Facilitate market development for biodiesel/B20 and higher blends by working with key players to address technical issues and potential market barriers and by opening up new regional and niche markets.

- Regional station network: Undertake a gap analysis to determine where B20 station placement should occur along the highest-potential regional corridors, and then provide funding actions and outreach activities that will accelerate the installation of biodiesel retail service stations and network.

- Terminals: Through funding actions, strive to expand the regional terminal blending infrastructure.

- Local authorities: Partner with local authorities (such as the fire marshal) to arrive at a variance for B20 pumps while awaiting UL listing for pumps and underground storage tanks. Learn from previous UL listing efforts with E85 infrastructure.

- Engine manufacturers: Support testing to ensure compatibility with post-2007 heavy-duty engines and communicate results to fleet managers via Clean Cities coalitions and partnerships (e.g., National Truck Equipment Association).

- Niche markets: Investigate new niche off-road markets (e.g., mining sector, landscape and grounds-maintenance equipment, railroads) on a regional basis, and provide information and publish data from ongoing and new demonstrations to interest business owners in testing biodiesel for equipment use.

- Peer Exchange: Work with successful biodiesel vehicle fleet managers (or identify successful retired senior fleet managers for a "Loaned Senior Executive" program) to share their lessonslearned experiences with fleet managers considering the switch to B20 or higher blends.

B. Provide coordinators with business and technical information, messaging, materials and tools, and workshops to educate stakeholders (particularly fleets) about biodiesel/B20 - including information about biodiesel quality and sustainability.

- Focus on B20: Build the case for B20 by working with coalitions to develop best practices and lessons learned reports about B20; provide current information on technology, regulatory requirements, costs, emissions data, and sustainability issues; and share information with fleets 
looking to use B20 blends. (Note that the use of B20 is mandated by some state agencies, e.g., Missouri, Indiana, Kentucky, and New Jersey.)

- Disseminate the biodiesel/B20 "business case" information through a range of Clean Cities communication channels, targeted in particular at helping coalitions drive regional market expansion for biodiesel.

- Leader recognition: Reward fleet managers who have successfully used B20 or higher blends in their vehicles in a variety of fleet applications to demonstrate to others that this fuel is a viable option.

- Educational/outreach gaps: Identify gaps in biodiesel education, outreach, and marketing and work with the biodiesel industry to address those gaps at national and local levels with fleets and coalition stakeholders.

- Biodiesel quality: Engage national laboratory researchers on a continuing basis to produce publications that inform OEMs, petroleum distributors, retailers, mechanics, first responders, and fleet managers about biodiesel fuel quality and characteristics.

- Biodiesel feedstock analysis: Determine the quantities of biodiesel being produced with varying feedstocks and marketplace potential.

- Biodiesel GHG benefits: Update the GREET model with data for soybean oil feedstock and other fuels such as algae, for determining the carbon footprints of these fuels.

\section{Accelerate the gathering of needed biodiesel technical data to use through Clean Cities channels to build understanding and acceptance for biodiesel.}

- Initiate a project to monitor biodiesel technical data being generated by laboratories, industry, and OEMs about the long-term durability and compatibility with diesel particle filters and $\mathrm{NO}_{\mathrm{x}}$ reduction catalysts; share those results through Clean Cities communications channels.

- Develop a project for coordinators to gather data related to issues or "how to use B20" from significant B20 users in their regions.

[For additional technology information, see Clean Cities paper: Status and Issues for Biodiesel in the United States.] 


\section{Strategic Direction - Fuel Economy Efforts}

\section{Fuel Economy Efforts}

\author{
Educate the consumer, business, and government about their \\ choices of vehicles and fuels so they can make smarter purchasing \\ and driving decisions for the highest impact on fuel economy.
}

\section{The Case for Strategic Priorities}

\section{Current Status -}

New vehicle fuel economy has been on the rise following two decades of stagnation. Results of a 2008 EPA study show that fuel economy improvements (1975 to 2005) now save U.S. motorists in excess of 80 billion gallons of gasoline each year - more than $\$ 200$ billion dollars annually at gasoline prices of $\$ 2.50$ per gallon. Moreover, given today's economic realities, businesses and their fleets, government organizations, and individuals are looking for the best opportunities to reduce costs.

Improved fuel economy saves money for businesses and consumers, reduces the nation's dependence on petroleum, benefits the environment by reducing carbon dioxide emissions, and improves air quality regionally across the country by decreasing emissions of smog-forming pollutants. Yet recent research shows that consumers undervalue fuel economy improvements because they are uncertain about what fuel economy savings a vehicle can achieve for them in real-world use.

In recent years, the U.S. government has promoted light-duty vehicle fuel economy through several federal incentives that reward consumers for making fuel-efficient choices when purchasing a new vehicle. These include the successful Cash for Clunkers program and tax credits for hybrid gaselectric cars, trucks, and plug-in electric drive motor vehicles (www.afdc.energy.gov/afdc/laws/). States have offered additional incentives, such as high-occupancy vehicle waivers, exemptions from vehicle excise taxes, and exemptions from mandatory emissions testing. Local incentives include such perks as free parking at designated locations.

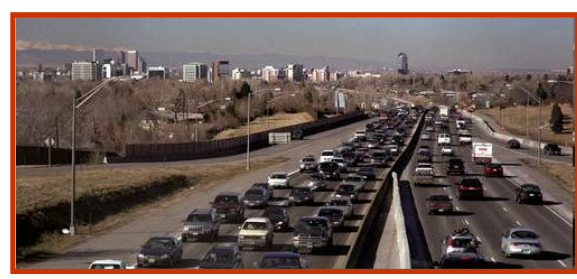

Clean Cities Fuel Economy

Current Example Initiatives

- Visitors to fueleconomy.gov (web/mobile versions) increased from 400,000 user sessions in 1999 to 39.1 million in 2009; continual information updates

- 2011 Fuel Economy Guide and Spanish version of Find and Compare Cars

- Successful innovations on fueleconomy.gov's "Find a Car," "Your MPG," "Driving and Maintenance Tips," and "MotorWeek" fuel economy features

3-5 Year Strategic Priorities

- Develop communications and media initiatives (developed nationally and deployed regionally) to draw public and business attention to the value of fuel economy.

- Develop and disseminate information about what driving choices/techniques can expedite fuel economy.

- Work with EPA to develop new ways to facilitate fuel economy by vehicle owners of new and used cars.

Through its network of coalitions, public/private partnerships, information outreach, meetings, educational material, and websites, Clean Cities continues to play a pivotal role in educating the public, fleets, and regions about fuel economy. A major source of information is the fueleconomy.gov website, sponsored by DOE Clean Cities with EPA-generated fuel economy data. The site attracts public attention (39.1 million user sessions in 2009 ) to the benefits of improved fuel economy - saving an estimated 400 million gallons of fuel in 2008. Some of the site's successful innovations include "Find a Car," to compare vehicles by fuel economy, fuel cost, and GHG emissions; "My MPG", a feature for users to share real-world MPG experiences; driving and maintenance tips; and "MotorWeek" fuel economy videos via public television. (Other examples of information outreach are included in the sidebar.)

As alternative vehicle and fuel technologies continue to evolve, consumers, businesses, and entire regions will want to understand issues, such as how to choose the right vehicles to increase fuel economy for a specific fleet, how the use of in-vehicle fuel economy monitoring devices may help drivers, how to maximize fuel economy 
through vehicle maintenance, and how to obtain the best mileage with the smallest environmental impact. Yet the underlying challenge remains: How can Clean Cities best encourage individuals to make educated decisions on their own behalf or for the benefit of their fleets, organizations, or regions in choosing and operating vehicles for highest impact on fuel economy and reduced environmental impact?

\section{DOE/Clean Cities Role -}

Clean Cities will continue to draw on the strengths and reach of its coalitions and stakeholders across the country to maximize public interest in fuel economy. The critical role for Clean Cities continues to be its ability to educate the consumer, business, and government to make choices that yield fuel and financial savings tied to fuel economy - through Clean Cities websites, traditional and social media programs, publications, and coordinator outreach. A major Clean Cities communications campaign developed with partners (such as corporations, major publications, proven social media, and driving organizations) could be designed to raise public and business attention to the impact of fuel economy with the objective to increase nationwide fuel economy significantly. Clean Cities' outreach could also focus attention on the relationship between fuel economy and new technologies on the market such as plug-in hybrid vehicles, battery electric vehicles, and hydrogen fuel cell vehicles - which require different methods of measuring fuel economy.

Key Constituencies for Fuel Economy - businesses and fleets, state and local governments' fleets, national/regional school bus and transportation associations, drivers education teachers, and the general public.

\section{3-5 Year Strategic Priorities}

\section{A. Develop communications/media initiatives (developed nationally and deployed regionally) to draw public and business attention to the value of fuel economy.}

- Partner with major organizations (e.g., OEMs, clean air groups, ad agencies, the American Automobile Association, sustainability-focused corporations, or oil companies) to develop a multifaceted, integrated, creative communications campaign to raise the public profile of fuel economy - thus drawing attention to Clean Cities, its portfolio of technologies, and fueleconomy.gov. (These initiatives would be developed nationally and deployed regionally.)

- Focus on drawing the attention of consumers and business to vehicles that achieve highest fuel economy.

- Partner with OEMs to develop a major advertising campaign targeted at educating the public and business about fuel economy.

- Recognize fleets that have made significant strides in reducing fuel consumption in their daily operations.

- Through a range of integrated communication channels (e.g., websites, social media), continue to educate consumers about the nuts and bolts of fuel economy - including the relationship of MPG and fuel savings, how to choose a car, how to interpret fuel economy for new hybrid/electric technologies, gas mileage tips, and more.

- Gather successful communication prototypes from local Clean Cities fuel economy materials and media outreach programs, as well as best-in-class media/educational/outreach materials from other organizations, to provide to other coordinators for their use in engaging partners in promoting the benefits of fuel economy to their customers and stakeholders.

- Pitch fuel economy story ideas and expert interviews to national and local media/reporters, with the intent of creating newspaper/radio/web interest in fuel economy.

- Examine the possibility of developing a fuel economy open blog to gather public contributions about best practices for achieving fuel economy.

- Partner with a national organization with regional presence (e.g., the American Automobile Association, Department of Motor Vehicles, national/regional driving schools) to publicize and offer training sessions (or build into existing driving lessons) to commercial and public drivers about the impact of driving choices/techniques that can expedite fuel economy. 
- Gather data on the effectiveness of driver training programs to improve fuel economy.

\section{B. Develop and disseminate information about what driving choices and techniques can expedite fuel economy.}

- Promote fuel economy monitoring devices (e.g., fuelly.com and gassavers.org gas mile trackers) to educate consumers and fleet operators about how driving behavior can contribute to fuel economy.

- Educate consumers about what approaches and choices do and do not support fuel economy.

- Reach out to school bus/transportation associations (national and regional) to educate their members about fuel economy.

- Reach out to drivers education organizations to incorporate "eco-driving" approaches into their curriculum.

\section{Work with EPA to develop new ways to facilitate fuel economy by owners of new and used cars.}

- Develop a labeling system (stickers) for new and used cars, including electric and hybrid vehicles, about greenhouse gas emissions and other fuel economy measures.

- Reach out to new audiences (including used car purchasers), make them aware of fuel economy, and involve organizations that can promote the new labeling for used cars.

[For additional technology information, see Clean Cities paper: Reducing Oil Use and $\mathrm{CO}_{2}$ Emissions by Informing Consumers' Fuel Economy Decisions: The Role for Clean Cities.] 


\section{Strategic Direction - Idle Reduction}

\section{$\underline{\text { Idle Reduction - For Trucks, Buses, and Municipal Vehicles }}$}

\author{
Advance widespread adoption of idle reduction technology practices \\ for trucks, buses, and municipal vehicles; validate the financial, \\ energy, environmental, and health benefits; and promote idle \\ reduction for commercial and public drivers.
}

\section{The Case for Strategic Priorities}

\section{Current Status -}

More than 2 billion gallons of fuel - equivalent to $1 \%$ of U.S. oil imports - burn unnecessarily each year in the United States during on-road vehicle idling. Moreover, idling reduces fuel economy, increases maintenance costs, and wastes more than $8 \%$ of commercial truck fuel. In 2008, Clean Cities coalitions displaced about 8 million gallons of petroleum fuel by reducing idling. Looking ahead, the coalitions have the potential to help save 1 billion gallons/year through successful idle reduction (IR) initiatives.

A range of technologies are available to help vehicles reduce fuel use, emissions, and noise. Such technologies include on-board equipment (e.g., diesel-fired heaters, battery or thermal storage air conditioners, auxiliary power units, and stop-start controls) and wayside units (electrified parking spaces). Payback on such investments can be two years or less. Idling reduction reduces a stopped vehicle's emissions of $\mathrm{CO}_{2}, \mathrm{NO}_{\mathrm{x}}$, and $\mathrm{PM}$ by a factor of three or more. This is potentially significant given that GHGs are estimated at 7.6 million tons $\mathrm{CO}_{2}$ annually for trucks idling overnight alone. These same idling trucks contribute 140,000 and 2,400 tons a year, respectively, of $\mathrm{NO}_{\mathrm{x}}$ and $\mathrm{CO}$, which are both smog-forming pollutants, to the atmosphere. Though a number of states and municipalities regulate idling, enforcement is difficult and costly. Typically, regulations apply to school buses and commercial vehicles, and restrict consecutive minutes of idling or total idling time.

\section{Future Prospects -}

Several factors inhibit the widespread adoption of idle reduction, including lack of knowledge and data about viable technology options, failure to incorporate IR equipment in new vehicle designs, legislative exemptions that allow trucks or other specialty or single-use vehicles to idle, lack of enforcement of idling laws, difficulty in getting loans for equipment purchases, and high capital costs for IR equipment. Clean Cities can draw on its educational, partnership, and training strengths and resources to tackle these issues and others.

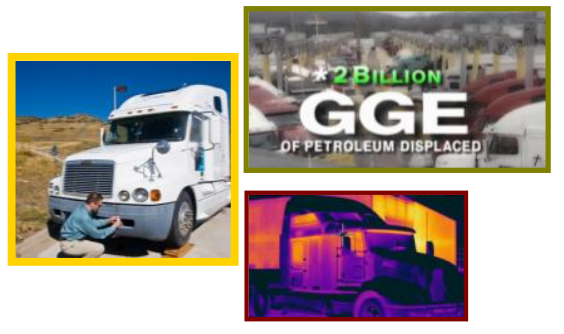

\section{Clean Cities Idle Reduction}

Current Example Initiatives

- DOE/EERE's monthly National Idling Reduction Network News, which keeps readers up to date on IR funding opportunities, grants awarded, and regulation changes

- AFDC website showing the locations of public IR facilities for heavy-duty trucks

- IR information meetings for stakeholders

- Support to local coordinators to implement IR initiatives

3-5 Year Strategic Priorities

- Form partnerships with fleets, trucking associations, and air quality agencies; fund installation of appropriate technologies; monitor and publicize operational results.

- Measure and capture technical data, enabling different types of users to choose the best technologies for their needs.

- Help coordinators educate stakeholders (fleets, trucking associations, school districts, municipalities, and the public), and train users about IR options/benefits.

\section{DOE/Clean Cities Role -}

Clean Cities can engage consumers and operators, school districts, the public transport industry, public and private fleets, trucking associations, and municipalities in idle reduction - particularly in providing education and training through the local coalition. Training can involve not only describing IR options, cost effectiveness, and benefits, but also providing information on driver operating habits and route and schedule planning, all of which can be adjusted to expedite payback on IR investments. Additionally, Clean Cities can influence technology deployment by creating informational and awareness-raising tools - such as baseline IR data from demonstration projects and fleet experiences, and information about IR emissions/benefits 
and costs - for coordinators to use with public and private fleets, local government, and other constituencies. On a regional basis, Clean Cities can help air quality agencies that fund equipment for emissions reduction to form collaboratives to enable recognition and sharing of State Implementation Plan (SIP) air quality credits.

Key Constituencies for Idle Reduction - fleets across all industries (including light-, medium-, and heavy-duty trucks), public fleets, transit and school buses and motor coaches, and passenger vehicles (including parents picking up children from school).

\section{3-5 Year Strategic Priorities}

A. Form partnerships with fleets, trucking associations, and air quality agencies; fund installation of appropriate technologies; monitor and publicize operational results.

- Fleets: Through Clean Cities national partnership initiatives, help regional fleet managers gain awareness of and understand available IR technology options. Projects can begin on a test basis to measure and record results that could help other fleets with their decision making.

- Trucking associations: Partner with trucking associations and EPA SmartWay to disseminate information about the financial and environmental benefits of idle reduction - and explore potential incentives to help truckers adopt it.

- Air quality agencies: Help air quality agencies develop cooperative agreements to track emission reduction from the use of on-board equipment across their regions. (The goal would be to enable agencies to receive SIP credits for the use of agency-funded on-board equipment that may be used outside of the specific nonattainment area.)

- Public knowledge transfer: Analyze the results of the ARRA transportation electrification grants that fund "wayside" projects in order to transfer knowledge to other projects and to educate fleets, trucking associations, air quality agencies, and the general public.

B. Measure and capture technical data, enabling different types of users to choose the best technologies for their needs.

- Document projects in which school buses and other vehicles are equipped with IR technology, with the intention of developing unbiased payback and other technical data.

- Measure idling emissions, start-up emissions, and time for the catalyst to warm up and cool down as a function of temperature for various vehicles. Such measurements will help answer questions about how long it makes sense to idle vs. turning the engine off, and how long to warm up (idle) before driving.

C. Help coordinators educate stakeholders (fleets, trucking associations, school districts, municipalities, and the public) and train users about IR options/benefits.

- Develop educational materials on IR, including marketing materials, case studies, and technology-comparison tools to support IR by fleets, school buses, municipal fleets, and more broadly within Clean Cities coalitions across the country. Include information on driving techniques and behaviors that facilitate IR.

- $\quad$ Redesign an IR portal on the AFDC website to share the educational materials and tools with specific information directed at different types of stakeholders/drivers.

- Study successful regional campaigns for idle reduction, and use proven components of these campaigns to raise public and business consciousness about the financial, energy-saving, environmental, and health benefits of idle reduction to different audiences.

- Conduct regional workshops to educate fleets, schools, municipalities, and the public on the value of reduced idling. 
- Provide Clean Cities coordinators with guidelines for when to turn off vehicles, and make information available on the fueleconomy.gov website as well as on the AFDC website's IR portal.

[For additional information, see Clean Cities paper: Idling: Cruising the Fuel Inefficiency Expressway, at wwwl.eere.energy.gov/cleancities/pdfs/idling_reduction_primer.pdf.] 


\section{Strategic Direction \\ Cross-Technology Strategic Priorities}

Several strategies are relevant to all or several of the alternative fuel and advanced vehicle technologies. Clean Cities' attention to building particular knowledge and resources will support all or many of the technologies. For example, the importance of monitoring GHG emissions and petroleum reduction savings is important to all of the technologies.

\section{Cross-Technology Strategic Priorities}

Technical Information and Data: Work with government and industry experts to capture/update/share technical data and information to support the portfolio of technologies.
Infrastructure Development: Involve state/local governments and private sector decisionmakers in learning about and supporting infrastructure development in regions and corridors with the greatest potential for expansion.

\section{Proposed Actions}

Greenhouse gas benefits: Partner with industry and ARRA recipients to capture key data on fuel economy/GHG/petroleum reduction for different fleet applications in each technology. Communicate the results to niche market fleets, industry and environmental associations, policy makers, and the public.

Codes and standards: Engage codes/standards developers and first responder experts to provide technical and safety data and to develop training modules to support each fuel/technology.

Federal, state, and local incentives: Review existing incentives that promote alternative fuels, electric drive, and renewable natural gas for vehicles and infrastructure development by region - and provide that information to coordinators via website and other channels.

Learning from experienced truckers: Partner with appropriate trucking association to make available its fleets' test data technology-by-technology for heavy-, medium, and light-duty commercial truck sector; provide case studies.

Briefings for decision-makers at member-based organizations: Present new findings and case studies in front of national/regional groups of decision makers, such as briefings tied to the National League of Cities, U.S. Conference of Mayors Council, National Governors' Association, National Association of State Energy Officials, and American Public Transit Association to support regional efforts for alternative fuels.

Partnerships with federal agencies: Enhance relationships and formulate new opportunities with federal agencies, such as U.S. Department of Agriculture, U.S. Environmental Protection Agency, U.S. Department of Transportation, U.S. Department of the Interior (National Park Service), and other DOE offices (e.g., Federal Energy Management Program) that have similar missions to Clean Cities and can build additional infrastructure in regions.

Regional/community development: Provide coordinators/stakeholders with tools, information, and best-practice strategies to plan effectively with OEMs, dealerships, utilities, fleets, and city and state governments to develop regional infrastructure/ community preparedness for appropriate technologies in the portfolio.

Assistance to project developers: Provide latest information on the state of the technology, demographics, and stakeholder data and information to facilitate planning and analysis for alternative fuel/technology project developers.

Retail integrated charging stations: Convene the right players (e.g., fuel providers, utilities, OEMs, government) to envision and help drive development for appropriately sited integrated charging stations on a local and regional level.

Key corridor evaluation: Develop a national study to evaluate current and planned infrastructure developments for all fuels for regional corridors across the country.

Annual awards: Implement an annual awards program to recognize regions, states, other federal initiatives, utilities, and fuel providers for progress in expanding/integrating infrastructures, which results in significant vehicle petroleum reduction. 
Fleets Engagement: Educate fleets to help them choose the right technologies for the right applications from the Clean Cities portfolio - and to attract notice to the fleets' progress.

Utilities Engagement: Engage gas and electric utilities and their affiliates to partner with Clean Cities.

Leveraging Partnerships. Work with a range of partners to expand the reach and impact of Clean Cities and partners' initiatives.

Technology \& Informational Toolkits: For each technology in the portfolio, develop a web/print toolkit with fuel and market primers - including presentations, templates, case studies, technical contacts, regional maps, and a "technology calculator."
Outreach and information sharing to engage fleets: Through the websites of Clean Cities, industry, and associations, as well as other avenues, expand outreach and engagement with many types of fleets - government, utility, business, schools, and airport and other transportation centers. Provide information about the portfolio of technologies/fuels, business case information, station locations, and other updated information.

Document fleet conversions and experiences: Work with business and municipal fleets to identify opportunities to convert portions of fleet vehicles to alternative fuels and advanced vehicle technologies, and document lessons learned from that process to share with other fleets.

Tiger Teams/users forums/retired or loaned senior executive fleet programs: Provide technical experts to troubleshoot fleet deployment. Provide opportunities for executives of similar fleet applications to collaborate and share information and strategies to overcome barriers.

Commendation of fleets: Recognize and publicize (via annual awards, Clean Cities website, and industry websites, etc.) local and national fleets that make significant progress in diversifying their fleets with technologies of the Clean Cities portfolio.

Fleets of off-road vehicles: Engage fleets with off-road vehicles that will build throughput at existing alternative fuel stations (e.g., B20, propane, natural gas).

Market expansion: Work with nontraditional regional partners, such as natural gas producers, independent system operators, regional transmission organizations, and electric utilities to expand natural gas and electric vehicle markets.

Utility business case: Make the business case for the benefits of using natural gas and electric vehicles in utilities' own utility fleets.

Communication: Provide utilities with lessons learned and business data, and help them promote natural gas/electric vehicles to other fleets and consumers in local communities.

Retail integrated charging stations: Involve utilities as key stakeholders, as well as OEMs, government, etc., to help drive development for integrated charging stations at homes, multifamily dwellings, and select public places.

Leverage collective resources: Partner with a range of key stakeholders, such as OEMs, fleets, utilities, municipalities, etc., to leverage the collective national/regional resources of Clean Cities and those organizations for greatest impact.

Partnering with associations: Work with major associations such as the American Automobile Association, National Association of Convenience Stores, Independent Petroleum Marketers Association, National Automobile Dealers Association, and the National Electrical Contractors Association to educate their members and expand visibility for vehicle technology choices in reducing petroleum use.

Nontraditional stakeholders: Seek out approaches to engage nontraditional players such as natural gas producers, state propane associations, the mining industry, and rental car agencies.

Co-develop communications initiatives: Develop highly visible communications and media initiatives with partners - such as a public campaign (developed nationally and deployed regionally) to draw public attention to the value of fuel economy and idle reduction and to the other technologies deployed by Clean Cities coalitions.

Develop business cases: Lay out the business case for each technology in the portfolio, including success factors, barriers, and economic information (e.g., return on investment, life cycle economics, petroleum savings, pricing) from business and government sources.

Case studies of ARRA projects: Analyze findings from ARRA-funded projects for Clean Cities portfolio technologies, and provide written case studies about "lessons learned" that can be used in a range of information-sharing initiatives on the website and for wide distribution to Clean Cities coalitions and fleet associations.

Technology calculator: Develop a "technology calculator" as a tool to help coalitions and fleets explore the best options for alternative fuels and vehicles, and to envision a potential cost justification/payback mechanism.

Train coordinators to use the "technology toolkit" effectively: Provide a webbased kit of presentation and supporting materials for each technology and provide a self-tutorial (on the Clean Cities website portal) to help coordinators know how best 
to use the toolkit to reach out to, educate, and assist local/regional partners and potential buyers.

Demonstration Vehicles: Provide demonstration vehicles to help coordinators and their coalitions expand regional exposure for advanced technology vehicles and alternative fuels.

Technical Training: Offer technical training across the country to support safe and best utilization of the technologies.
Public awareness: Build consumer and fleet recognition and confidence with local displays of new OEM products as they are introduced into the market, while working closely with local dealerships and other stakeholders as appropriate.

Technician, fleet, first responder, and consumer training: Continue to offer training across the country that will help ensure performance, safety, and emission reduction benefits of each technology, and identify gaps in services or regions not served.

Eco-car driving: Educate consumers and fleet managers about the benefits of ecocar driving and not idling to achieve higher fuel economy. 


\section{Organizational Strategies \\ Optimize Coalition Effectiveness and Sustainability}

\section{Optimize coalition leadership, engagement, and communication effectiveness to ensure long-term regional growth and sustainability in reducing petroleum use in on-road vehicles.}

\section{The Case for Strategic Priorities}

Essential to DOE Clean Cities' ability to deliver on its mission is the strength and effectiveness of the nearly 100 coalitions and the ever-growing impact of their work throughout the country. Clean Cities is dedicated to support these local organizations and the challenging work they undertake. As history shows, the ability of individual coordinators to influence decisions and successfully engage their coalitions in deploying alternative fuel and advanced vehicle technologies has a direct impact on overall success in reducing petroleum year after year in their communities. Ongoing efforts to strengthen the coalitions and nurture the network are critical for Clean Cities to meet its goals over the next three to five years.

To support these premises, in 2009, ASG Renaissance was asked to study the Clean Cities factors essential to petroleum displacement and operational efficiencies. The study confirmed the essential role of coordinators as leaders and their increased impact by working more than part-time on Clean Cities duties. Across the many factors studied - including gasoline gallon equivalents and coordinators' time, funding, and experience - a consistent correlation was identified between the amount of time a coordinator devoted to Clean Cities work and the amount of petroleum his or her coalition displaced. The study also highlighted the value of "collegiality" among coordinators as together they develop effective solutions and strengthen their coalitions. In addition, the network of coalitions can play a critical role in changing consumer perceptions and behaviors.

ASG also reviewed organizational business models, and on average, independent nonprofit organizations allowed coordinators to dedicate more time to the goals of Clean Cities. Ultimately, this model contributes to greater petroleum displacement. In parallel with the objective to determine key elements that contribute to coalition effectiveness, opportunities for improvements in efficiency were also explored. Current collaboration among coalitions was found to be high, including hosting of events, project development, and sharing of expertise in a variety of areas. The report strongly recommended these connections continue to be fostered.

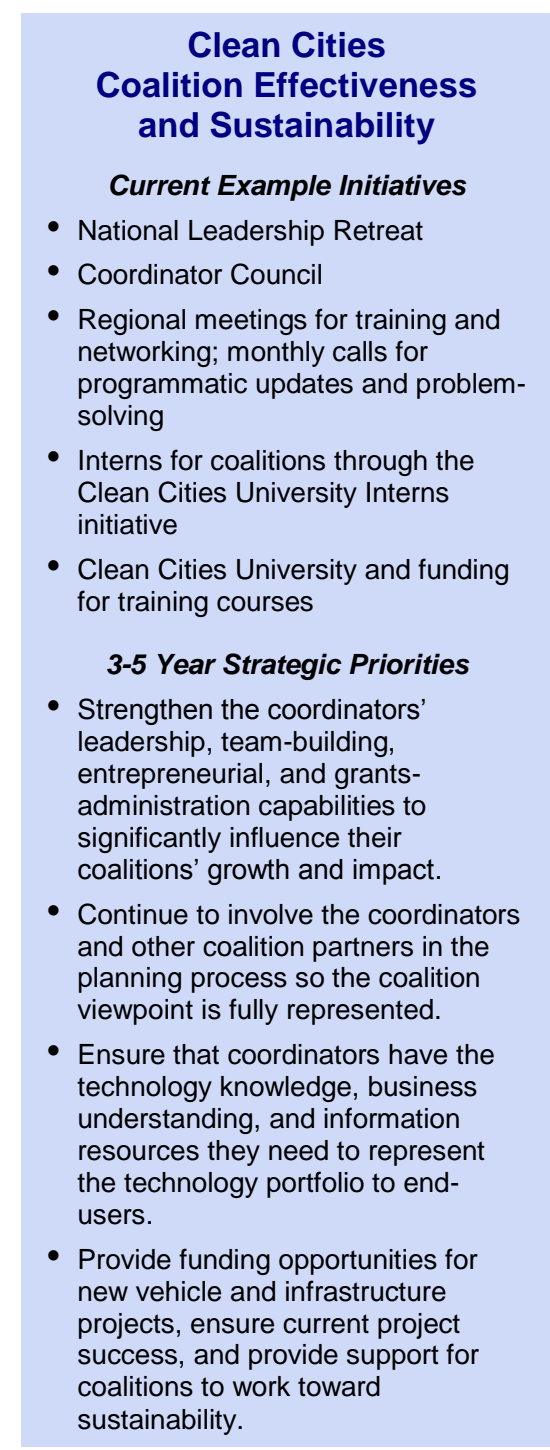

The information that was gathered through the ASG Renaissance Growth and Effectiveness Project for Clean Cities, and the interview process of Cambridge Concord Associates in developing this plan, reinforces the value of providing the coordinators with the educational opportunities, resources, technical assistance, and tools they need to maximize the effectiveness of their coalitions. Moreover, the important Clean Cities initiative to build solid national partners will also provide coalition opportunity, support, and ongoing stability.

It is essential for the Clean Cities program to listen to and collaborate with coordinators to understand their needs and how the program can effectively enable them to draw on their own expertise and 
experience in carrying out the Clean Cities mission. Clean Cities can tap into the coordinators' expertise to help define overall program growth and direction. The Coordinator Council provides an important asset to reinforce and encourage collaboration across the Clean Cities coalitions.

While there are a range of recommendations that could be made, this plan selects and highlights a few important strategic points.

\section{3-5 Year Strategic Priorities}

A. Strengthen the coordinators' leadership, team-building, entrepreneurial, and grantsadministration capabilities to significantly influence the growth and impact of their coalitions.

- Continue to strengthen coordinators' leadership and communication skills through Clean Cities University courses and webinars, as well as specific training modules offered locally and/or funding for course work at local colleges or approved training courses offered by outside organizations.

- Provide a mentoring program for all designated coalitions to participate in (developed regionally and replicated across the country) and provide interns to competitively selected coalitions for additional workforce.

- Encourage collaboration across coalitions as a way to create projects with more impact (i.e., multistate corridor and promotional projects).

- Offer management development opportunities - such as nonprofit administration, nonprofit board development, managing people, and team building - through Clean Cities University, DOE Clean Cities-sponsored meetings, and/or funding for coursework at local colleges or approved training courses offered by outside organizations.

- Undertake redesignation process to strengthen local support and commitment to key strategic directions of the Clean Cities coalitions.

B. Continue to involve the coordinators and other coalition partners in the planning process so the coalition viewpoint is fully represented.

- Ensure that each coalition has an annual plan in place and continues to expand on that plan in future years (building on the new initiatives that are under way).

- Develop a "smart growth" approach for expanding coalitions where appropriate and working in new areas of the United States that are not covered but have high density of fleet traffic.

C. Ensure that coordinators have the technology knowledge, business understanding, and information resources they need to represent the technology portfolio to end-users.

- Educate coordinators about the eight technologies, development timetables, niche markets, infrastructure needs, and regional/national prospects. (See, for example, programs by the National Alternative Fuels Training Consortium and other key constituencies, and virtual/workshop training modules provided through the Clean Cities University.)

- Work with coordinators and industry to develop a print/web toolkit with updated fuel and market primers for each technology, including presentation materials and templates and technical contacts.

- Lay out the business case for each technology in the portfolio, including success factors, barriers, and economic information (e.g., return on investment, life cycle economics, petroleum savings, pricing), from business, government, and public sources.

- Develop a technology calculator to assist coalitions/fleets in exploring best options for alternative fuels and vehicles, and to envision a potential cost justification/payback mechanism. 


\section{Provide funding opportunities for new vehicle and infrastructure projects, ensure current project success, and provide support for coalitions to work toward sustainability.}

- Provide training in grant writing, management, auditing basics, data collection, and data analysis to help coordinators maximize their success in procuring and managing grants.

- Investigate corporate and other philanthropic foundations that may be interested in local Clean Cities programs or the national program. (Corporations involved in a national partnership initiative may lead to contacts in their corporate foundations.)

- Identify opportunities for training related to specific federal programs (e.g., block grants, Clean School Bus USA, Clean Diesel Initiative, Congestion Mitigation and Air Quality Improvement Program [CMAQ], and EPA supplemental funds and renewable natural gas programs) and develop appropriate training modules and materials.

- Develop performance metrics that will generate mentoring opportunities and new models of operation.

- Train and enable coalitions to develop annual operating plans and long-term objectives that strengthen their capacity and success as highly effective organizations. 


\title{
Organizational Strategies \\ Increase Recognition, Build Awareness, and Educate
}

\author{
Increase the recognition and awareness for Clean Cities and its coalitions as a leading source of \\ information about alternative fuels and advanced vehicle technologies, and educate \\ organizations, government, and the public about how to reduce petroleum use in on-road \\ vehicles.
}

\section{The Case for Strategic Priorities}

Over the past 15 years, Clean Cities has created multifaceted communications resources and highly effective initiatives to support its mission and the work of its coalitions and partners. Looking ahead, Clean Cities can build on and strengthen this platform in innovative ways that maximize the impact of traditional and next-generation social media communications resources to expand its reach and attract many more organizations and individuals that can support its mission. Educational outreach will play a critical role.

Through highly strategic marketing and communications initiatives, Clean Cities wants to grow its recognition and build awareness for its mission in ways that will draw in more attention - and personal and business commitment - to this country's capacity to reduce petroleum in on-road transportation. To have the public regard Clean Cities and its coalitions as the go-to organization for reducing petroleum use in transportation, Clean Cities needs to make the public aware of the organization as a reliable information source about alternative fuels and advanced vehicle technologies. Clean Cities should also grow in its recognition as a conduit for organizations to come together to achieve shared objectives.

In essence, Clean Cities has multiple roles: as an information center, educator and trainer, developer and funder, partner, and a convener that brings organizations together to reduce their own petroleum use and that of their customers. Moreover, Clean Cities has a unique (and potentially powerful) opportunity to work with its partners on both national and regional levels to cocreate strong marketing and communication initiatives that draw significant attention to the work they are doing together to promote energy security.

\section{3-5 Year Strategic Priorities}

A. Implement an integrated media/communications program to escalate awareness of the work of Clean Cities coalitions, stakeholders, and partners - with a strong emphasis on engaging the public.

- Shape core messages to cause people and organizations to take steps to reduce their own petroleum use in vehicles/fleets ("Why is this important for me?"). Identify Clean Cities and partner spokespersons to speak to these messages nationally and regionally on an ongoing basis.

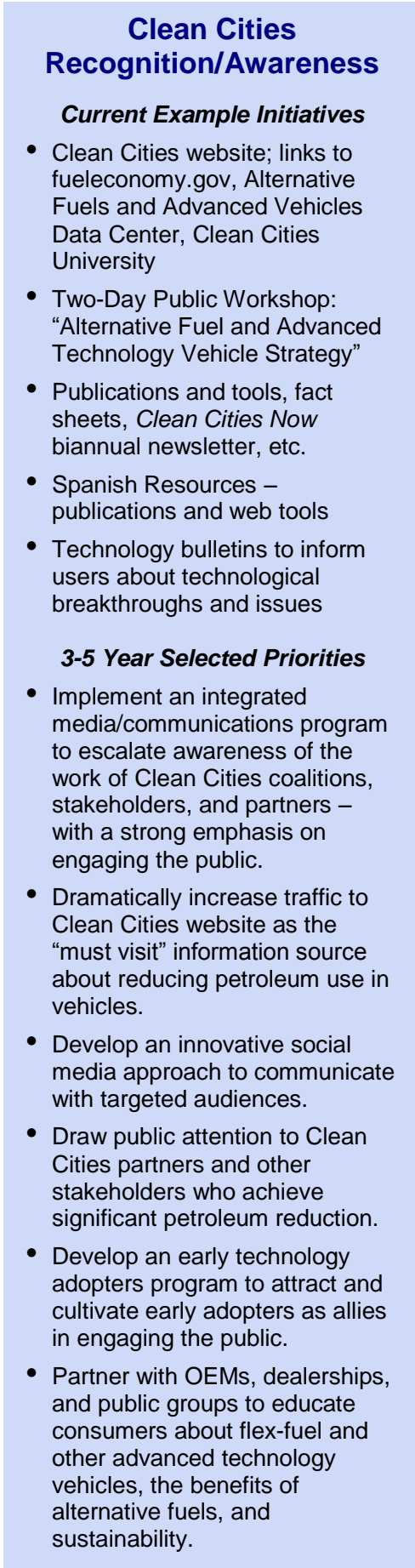


- Define how the messages should be used effectively throughout all

Clean Cities communications initiatives, materials, website, and partnerships, etc.

- Clarify how to talk about Clean Cities relative to its parent and partner government organizations to reduce confusion - and to strengthen understanding of Clean Cities.

- Explore options for interesting an outside public relations/media firm in working in partnership with Clean Cities on conceiving and launching a campaign with organizations (such as the Ad Council) - perhaps focused on fuel economy.

- Involve (and partner with) selected coalition stakeholder organizations in this campaign (drawing on communication/marketing strengths of partners) - work at national and regional levels.

- Implement a tactical, ongoing media program dedicated to getting Clean Cities coalitions and stakeholders in the media/press on a continuing basis.

Work with an agency to develop specific stories with editors/reporters on an ongoing basis about Clean Cities coalitions and the work they are doing.

Write/publish papers by laboratory technology experts or co-authored with partner organizations as trade articles. (Include shorter-length articles from existing tech papers to submit to trade magazines.)

For coordinators, create Clean Cities media outreach kits that can be customized with coalition logos (e.g., short articles on alternative fuels/fuel economy to run in local papers, and possibly public service announcements for local radio/television/blogs).

- To maximize return for each conference or meeting speech given, define additional media outlets, speaking opportunities/venues, or webinars to share the same information/messages with different audiences.

Post media stories on a visible place on the Clean Cities website where all visitors can see what's new.

- Cultivate media relationships with a select number of organizations that have equal stature and aligned goals with Clean Cities to reduce petroleum use - and co-develop select programs so that both organizations gain greater visibility.

B. Dramatically increase recognition for and traffic to the Clean Cities websites as the userfriendly "must visit" sources of information about reducing petroleum use in vehicles - that direct visitors to areas of particular interest/benefit to meet their needs.

- Reconfigure the homepage to let different types of visitors rapidly understand what Clean Cities is and how to access relevant information for them - and explain/position the role of fueleconomy.gov. (Review website for ease of use.)

- Guide target user groups arriving on the homepage to specific information of interest to them. (As an example, Clean Cities has an effective, visible area for coordinators: "Coordinator Toolbox.")

- Create a fleet manager's area ("Info Depot"), that directs visitors to information about vehicle technologies and fuels, approaches to choose the right vehicles for a fleet, case studies and lessons learned from other fleets, comparative studies of interest to fleets, information about flex fuel vehicle availability, station locations by fuel type, etc. (So as not to replicate existing content, include specific links to information provided in the AFDC and the fueleconomy.gov websites.)

- Create a media/press area to facilitate access to information needed by journalists and writers for research, articles, or websites.

- Implement a web-based outreach initiative to connect consumers to the AFDC tools that show where to purchase fuel in their regions (i.e., AFDC refueling locator, smart phone applications, 
mapping, Clean Cities Vehicle Buyer's Guide, and future GPS capabilities), and how to understand sustainability issues.

- Develop social media tools to provide this information in ways that will appeal to new consumers.

- Promote and provide links for consumers to learn what flex fuel and other vehicles are available (e.g., www.fueleconomy.gov; www.afdc.energy.gov/afdc/vehicles).

C. Develop an innovative, organized social media approach for Clean Cities to communicate with targeted audiences (e.g., the public, early technology adopters, fleet managers, energy and environmental reporters/media, educators, young adults).

- Define Clean Cities' expectations and goals for social media and what mix of Facebook, LinkedIn, YouTube, webinars, etc., will achieve those objectives (e.g., reaching and getting comments back from the public, ongoing communication with early adopters).

- Implement a social media program targeted specifically at early technology adopters, learn from that experience, and then expand to other audiences, such as fleet managers, as needed.

- Consider the value in assigning an individual to create social media content part-time on behalf of Clean Cities to raise visibility, particularly for fuel economy and Clean Cities' role in improving fuel economy.

D. Draw public attention to Clean Cities' partners and other stakeholders who achieve significant petroleum reduction.

- Establish a national partnership initiative that provides recognition to Clean Cities partner fleets or other organizations that are deploying significant numbers of alternative fuel and advanced vehicle technologies or adopting idle reduction technologies and fuel economy practices.

- Develop an annual corporate awards program that recognizes and brings public attention to fleets that are making significant progress.

- Tie this program (and other awards programs) into the media/communications and social media initiatives (and to the recipients' media programs) to maximize visibility for the awarded fleets or partners - and to the Clean Cities mission.

E. Develop a Clean Cities early technology adopters program to attract and cultivate early adopters as important allies in engaging the public in choosing vehicles/fuels to reduce petroleum use.

- Develop a media program targeted at attracting early technology adopters to Clean Cities website, reaching them through publications they read, conferences they attend, and initiatives they support, and developing articles or other outreach in those venues to draw them to Clean Cities.

- Create specific content for early technology adopters on the Clean Cities website, and create surveys and blogs to benefit from their knowledge and experiences and provide information of interest to them (a "two-way street"). This may include information on how they can become involved with their local coalition.

F. Partner with OEMs, dealerships, and public information groups to educate consumers about flex-fuel vehicles, the benefits of alternative fuels, and sustainability.

- Develop outreach initiatives, using the Clean Cities website and social media to connect consumers to the AFDC tools showing where to purchase flex-fuel vehicles and alternative fuels in their regions (i.e., AFDC refueling locator, smart phone applications, mapping, Clean Cities Vehicle Buyer's Guide, and future GPS capabilities), and how to understand sustainability issues. 


\section{Organizational Strategies Create Strong, Innovative Partnerships}

Create strong, innovative partnerships to drive the growth and reach of Clean Cities at the national level and through its local coalitions for greatest impact-recognizing that partners will extend coalition opportunity and stability.

\section{The Case for Strategic Priorities}

Partnerships at both the national and local levels have always been a hallmark of Clean Cities. Now more than ever, partnership efforts need to be focused as more national companies see the importance of alternative fuels and advanced technology vehicles. Major corporations committed to sustainability, particularly those with large fleets, represent high-potential partners for Clean Cities to expand its impact, reach, and visibility.

Moreover, the strategic role for national partnerships to strengthen coalition effectiveness was emphasized in recent research and analysis by ASG

Renaissance. Such collaboration provides the partner organizations with access to unbiased Clean Cities information and expertise from government research laboratories. These connections allow Clean Cities to convene a broader range of constituencies toward a common goal, and extend its reach across partners' communication channels. At the same time, Clean Cities cannot consider national partnerships successful unless the visibility, knowledge, and other benefits extend to regional coalitions. Some partners are indeed interested not only in working at the national level, but also in joining local coalitions and using existing infrastructure or collaborating on building new infrastructure for their fleets. Solid national partnerships will also provide local opportunities and support for coalitions to strengthen their long-term stability.

\section{3-5 Year Strategic Priorities}

A. Partner with a range of key stakeholders to leverage the collective national/regional resources of Clean Cities and other organizations for greatest impact.

- Fleet concentration: Engage national corporate fleets to work with Clean Cites coalitions at the regional level - and across regions. [under way]

- Regional/National: Encourage coalitions with local/regional partners that are part of national organizations to move selected relationships up to the national level for Clean Cities to benefit other coalitions and grow the market.

- National Park Service: Develop relationships with local national parks for vehicle projects and education aimed at reducing petroleum consumption of visitor and fleet vehicles at the parks. 
B. Develop Clean Cities specialized stakeholder meetings or conferences that bring together key partners (e.g., DOE, Clean Cities leadership, coalition coordinators and stakeholders, cities, and states) to explore priorities for the next 3-5 years.

- Convene a biennial meeting of officials from various states responsible for vehicle deployment programs in their states to meet with Clean Cities and DOE to discuss respective five-year program and funding priorities and opportunities for working together.

- Host a national stakeholder summit that will showcase the projects and priorities of the local coalitions to help further develop the strategies that are outlined in this document. [Planning is under way.]

C. Work with partners to promote various vehicles and infrastructure available to help coordinators and their coalitions expanding regional exposure for advanced technology vehicles and alternative fuels.

- Making demonstration vehicles available: Promote opportunities with dealers and industry locally to showcase demonstration vehicles for marketing and education of fleet and early adopter audiences.

- Sharing fleet data: Partner with appropriate trucking companies, delivery companies, and other fleets to make available their fleets' "test data" and provide case studies about what was learned to other companies with similar fleet applications. (Case studies about the ability of truckers or large companies to reduce petroleum could be interesting stories for regional press.)

D. Accelerate project and infrastructure development by working as a partner to support corporate developers, OEMs, fuel providers, utilities, and a wide range of stakeholders.

- Assistance to project developers: Provide infrastructure data by region to corporate developers to facilitate planning and analysis for their current and future fleet needs. This includes propane and natural gas station placement, and E85 and B20 stations in the Midwest region as the result of ARRA and other previously funded Clean Cities projects.

- Retail integrated charging stations: Convene stakeholders (e.g., charging stations developers, utilities, OEMs, government) to envision and help drive development of integrated electric vehicle recharging stations on a national and regional level. Work with OEMs and dealerships to help leverage message and information dissemination to consumers.

- Continue to work with national laboratory partners to make the case for greater throughput at existing biofuel stations and expand the market where it makes economic sense by informing coordinators, other stakeholders, and the public about indirect land use or other sustainability findings and technical issues.

- Assistance to OEMs: Work with OEMs as they launch new alternative fuel and advanced technology vehicles, with particular attention to dealers located in Clean Cities; work with permitting officials to ensure timely infrastructure upgrades and targeted expansion. 


\section{Appendix A}

\section{Strategic Planning Process}

The management team of DOE Clean Cities initiated a strategic planning process in the fall of 2009 to focus on maximizing the impact of its programs and funding. As a way to launch the planning process to engage the many stakeholders who work with Clean Cities, they held a two-day Alternative Fuel and Advanced Technology Vehicle Strategy Workshop in Washington, D.C., in September 2009. Technology experts from Argonne National Laboratory, National Renewable Energy Laboratory (NREL), and Oak Ridge National Laboratory presented highlights of their briefing papers about each technology in the Clean Cities portfolio: E85, biodiesel, natural gas, renewable natural gas, propane, electric-drive technologies, idle reduction, and fuel economy.

Representing a wide range of organizations, the workshop participants discussed each technology, providing many and diverse ideas. Energetics, an independent contractor, facilitated the workshop and the discussions around four Clean Cities strengths: partnerships and collaboration, education and information sharing, technical support and training, and demonstration and deployment.

Recognizing that Clean Cities required an overarching strategy to help plan future priorities, Clean Cities engaged Cambridge Concord Associates (CCA), an independent consulting firm, to work with senior leadership to develop a strategic framework for future decision making. Building on the knowledge shared at the workshops, the CCA team had continuing conversations with the Clean Cities leaders over the next couple of months. The planning process was also informed by the consultants' interviews with a range of Clean Cities regional managers from the National Energy Technology Laboratory (NETL) and Golden Field Office, coordinators and council members, expert authors of the technology papers, auto manufacturers, key communications staff from NREL, principals of ASG Renaissance, as well as representatives of relevant associations. Each person interviewed has had direct involvement with Clean Cities for an extended period of time.

Based on the workshops, subsequent meetings, interviews, and conversations with the authors of the technology papers, the consultants analyzed the technologies and developed a set of briefs for each technology - including the current state of the technologies, possibilities for greatest leverage, and possible strategic choices for Clean Cities to achieve greater impact in supporting each technology.

The draft framework for the strategic plan was presented in January 2010 to DOE Clean Cities management and regional Clean Cities managers, technology analysts from government laboratories, and principals of the consulting firm ASG Renaissance and New West Technologies to benefit from their roundtable discussion. Following that meeting, and through further discussions with Clean Cities leaders, the draft final Clean Cities Strategic Plan was developed over the following weeks for presentation to DOE in August. After receiving feedback from DOE and, subsequently, the Clean Cities Coordinator Council, all Clean Cities coordinators who attended the September 2010 Leadership Retreat were given a draft of the plan with the opportunity to provide comments. These comments were incorporated as deemed appropriate to finalize the Clean Cities Strategic Plan. 


\section{Appendix B}

\section{Interview Participants}

Technical Paper Authors and Strategic Plan Reviewers

- Biodiesel (Bob McCormick, Wendy Dafoe, Teresa Alleman, NREL)

- E85 (Margo Melendez, Wendy Dafoe, Kristi Moriarty, NREL)

- Natural Gas and Propane (Andy Burnham, Marcy Wood Werpy, Argonne)

- Renewable Natural Gas (Marianne Mintz, Argonne)

- Idling Reduction Technologies (Linda Gaines, Terry Levinson, Argonne)

- Fuel Economy (David Greene, Janet Hopson, Oak Ridge)

- Electric Drive Vehicles (Dan Santini, Argonne)

\section{Other Stakeholders}

- Tim Gerlach, Minnesota Corn Growers Association

- Henry Hogo, SCAQMD

- Curt Magleby, Ford Motor

\section{Clean Cities}

- Beth Ardisana, ASG Renaissance

- Brad Beauchamp, Midwest Regional Manager

- Michael Bednarz, West Regional Manager

- Samantha Bingham, Coordinator, Chicago

- Wendy Dafoe, NREL
- Heloise Froelich, Coordinator, City of Los Angeles

- Lori Hines, ASG Renaissance

- Kay Kelley, Northwest Regional Manager

- Neil Kirschner, South Central Regional Manager

- Dave Konkle, former Coordinator, Ann Arbor

- Michael Laughlin, New West Technologies

- Margo Melendez, NREL

- Mindy Mize, Coordinator, Texas

- Jonathan Overly, Coordinator, East Tennessee

- Steven Richardson, Southeast Region

- Erin Russell-Story, Mid-Atlantic Regional Manager

- Michael Scarpino, NETL, Lead, Regional Manager

- Heather White, NREL

- Barb Wolfe, New West Technologies

- Members of the Clean Cities Coordinator Council

Extensive Reviews Conducted by:

- Linda Bluestein, DOE

- Shannon Shea, DOE

- Dennis Smith, DOE

- Marcy Rood Werpy, Argonne 